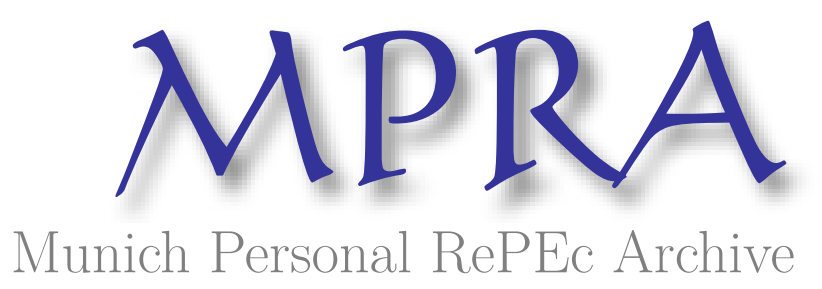

\title{
Bank competition, financial reform and institutions: The importance of being developed
}

Delis, Manthos D

2 July 2010

Online at https://mpra.ub.uni-muenchen.de/31035/

MPRA Paper No. 31035, posted 21 May 2011 13:43 UTC 


\title{
Bank competition, financial reform and institutions: The importance of being developed
}

\author{
Manthos D. Delis \\ University of Ioannina, Ioannina, Greece
}

\begin{abstract}
In this paper we estimate the degree of market power at the bank-level for 84 banking systems worldwide. Subsequently, we analyze the sources of bank competition, placing emphasis on the impact of financial reform and the quality of institutions. We find that financial liberalization policies reduce the market power of banks in developed countries with advanced politico-institutional milieus. In contrast, banking competition does not improve at the same pace in countries with weaker institutions and a lower level of economic development. The results hold across a wide array of identification tests and estimation methods. The main policy implication to be drawn is that a certain level of institutional maturity is a precondition for the success of reforms aimed at enhancing competition and efficiency of banking markets.
\end{abstract}

JEL Classifications: P4; G2 ; L1 ; C1

Keywords: Bank competition; Financial reforms; Institutional development 


\section{Introduction}

The political economy literature has uncovered a significant relationship between the financial and banking system and state institutions (e.g. Andrianova et al., 2008). Similarly, the banking literature has placed strong emphasis in examining the level of banking sector competition in a number of countries (see Carbo et al., 2009, and references therein). However, less consideration has been given to the financial liberalization policies and the political and institutional forces that shape competition in the banking sector. This seems to be of primary importance, since financial liberalization aims to improve efficiency and competitive conditions in the banking sector and, subsequently, economic outcomes (Demetriades and Andrianova, 2004). Yet, experience shows that the short- or medium-term outcomes of these policies are related to concentrated banking markets (Delis, 2010) or increased financial instability (Demirguc-Kunt and Detragiache, 1998). This paper is the first attempt to elaborate on these issues by emphasizing the role of institutions in the financial liberalization-bank competition nexus. To this end, we investigate empirically the separate and combined effect that the institutional environment and financial liberalization policies have on bank competition (lower market power of banks) across a large set of countries.

But why are institutions potentially important determinants of bank competition and an important element in explaining the pattern of the financial liberalization-bank competition nexus? The wave of financial liberalization policies of the 1980s and 1990s led unambiguously to increased competition in the banking sector, primarily through the removal of entry barriers, liberalization of product restrictions and elimination of intra-sectoral controls (Claessens, 2010). These reforms were stimulated, first and foremost, by the political-economy debate on the potential positive impact of financial liberalization policies on economic outcomes. King and 
Levine (1993), Cetorelli and Strahan (2006) and Jayaratne and Strahan (1998), among many others, suggest that financial liberalization increases the long-run growth rate of the economy by fostering financial development. In addition, liberalization policies usually involve extensive privatization of formerly state-owned banks, which is in turn positively related to improved efficiency and stronger incentives to invest in new and better technology. Last but not least, Galindo et al. (2007) show that financial liberalization improves the allocation of investments especially in developing countries, and Delis et al. (2010) that stricter banking regulations, especially those associated with market discipline and activity restrictions, widen the distribution of income.

This positive view of financial liberalization is somewhat clouded by the marked increase in financial fragility experienced in both developed and developing countries in the 1980s and 1990s. Demirguc-Kunt and Detragiache (1998) show that the probability of financial fragility following financial liberalization policies is positively associated with weaker institutions, especially those related to the rule of law, the level of corruption and contract enforcement. On the same line, the work of Jean-Jacques Laffont (as summarized by Estache and Wren-Lewis, 2009) shows that institutional weaknesses in developing countries make the optimal reform policy different from that of developed countries. Tirole (1991) suggests that liberalization and privatization without preparatory de-monopolization would create a segmented market dominated by private firms with considerable market power. This is because under central planning, production takes place by only a few entities, while foreign penetration is unlikely to occur in the short-term. Joskow et al. (1994) point out that, in the case of Russia, product-level concentration of production created monopoly problems and, although restructuring prior to 
privatization would have been desirable, political and institutional underdevelopment constraints largely precluded it.

A parallel line of literature argues that private ownership and management have not improved performance, especially in sectors where there is no competition (for a review, see Boubakri et al., 2008). Also, varying transition paths from central planning to a market economy have resulted in different legal and politico-institutional frameworks, which have consequently affected the efficient functioning of banking systems. For example, in some cases, privatization was implemented so as to benefit the political power holders of the previous regime. This led to what some have described as "political capitalism", which encourages oligopolistic market structures (Staniszkis, 1991). In other banking systems, a stark dichotomy of ownership between state and foreign private capital has been observed, in what has been branded "capitalism without capitalists" (Eyal et al., 1998). Finally, the relatively weak legal systems of developing and transition countries, as well as the high levels of networking and corruption in the respective financial systems, may have limited the strength of competitive forces at least as long as financial integration has not advanced. First-hand evidence on this is provided in the recent work of Beck and Hesse (2009) for the stagnant lending rates in the banking system of Uganda and of Brock and Suarez (2000) for Latin American countries.

Based on the above opposing arguments, we expect that financial reform policies aiming at enhanced liberalization will drive market power of banks down. However, this effect may be less potent or delayed for countries with relatively weak institutions. Is this the case? On this basis the present empirical analysis answers three main questions:

(i) Are the competitive conditions in the banking sectors of countries or groups of countries different? 
(ii) Did financial liberalization policies succeed in generating competitive conditions in the banking systems worldwide?

(iii)What was the role of the institutional environment in shaping banking sector competition during and after the financial reforms?

To answer these questions, we first estimate the market power of individual banks in 84 countries over a relatively long time frame that encompasses periods of financial reform. We use a new method to estimate market power, namely the indicator proposed by Boone et al. (2005) and Boone (2008), which has clear theoretical underpinnings and is robust to a number of specification issues relative to our sample. In doing this, we essentially provide a new index of market power for a large number of banking systems worldwide. As a robustness check, we also use the Lerner index and a concentration ratio. Subsequently, we examine whether financial liberalization policies improve bank competition, and whether this effect is uniform across countries with different levels of institutional strength.

The results show, on the one hand, that competitive conditions are quite different between countries (and groups of countries) and, on the other, that financial reforms are important in containing the market power of banks. Yet, this importance diminishes in countries with weak institutions and a comparatively low level of economic development. Therefore, we suggest that relatively underdeveloped banking systems, in less advanced politico-institutional milieus, overall fail to benefit from reforms in their early stages. Among the institutional characteristics, improved transparency (low corruption) and bureaucratic quality are the single most important prerequisites for financial reforms to have a significant impact on bank competition. In addition, in developed countries these effects are more pronounced for large banks, which are usually the ones that possess higher market power. Thus, a concentrated 
banking system does not entail a non-competitive banking system if institutions are robust. In a nutshell, the policy implication to be drawn is that a certain level of institutional maturity is a precondition for the success of reforms aimed at enhancing competition in the banking sector.

Our study is naturally related to a large literature on banking sector competition. Studies closer to our goals are those of Claessens and Laeven (2004) and Hasan and Marton (2003). Their findings suggest that the abolishment of activity restrictions, flexible approaches to privatization and liberal policies towards foreign banks' involvement with the domestic institutions helps building a relatively stable, more competitive and increasingly efficient banking system. Other studies (e.g. Bikker and Haaf, 2002; Carbo et al., 2009; Delis, 2010) estimate the level of competition in several banking industries, but do not examine the institutional and political forces that shape banking-sector competition. However, these studies do show that banking sectors in former centrally-planned economies are characterized by higher market power compared to developed banking systems, thus providing another strong incentive to trace the differences in these findings in the theoretical arguments of the political economy and development literature highlighted above.

The rest of this paper is structured along the following lines. Section 2 discusses the methodology used to estimate market power at the bank-level and reports average results by country and over time. Section 3 presents the explanatory variables used to study the relationship between bank competition, financial liberalization and institutions. Section 4 presents the empirical findings and Section 5 concludes the paper. 


\section{Empirical model and estimation of bank market power}

The general empirical model used to study the relationship between banking sector competition, financial liberalization and institutions is of the following form:

$$
M P_{i t c}=b_{0}+b_{1} F R_{t c}+b_{2} I E_{t c}+b_{3} M_{t c}+b_{4} B_{i t c}+\varepsilon_{i t c} .
$$

In Eq. (1) the market power $M P$ of bank $i$ at time $t$ that operates in country $c$ is written as a function of the time- and country-dependent financial reforms variable $F R$; a vector of variables

$I E$ that characterize the institutional environment of each country; a vector of control variables $M$ that reflect the macroeconomic conditions in the banking systems examined; and a vector of bank-level control variables $B$. Finally, $\varepsilon$ is the stochastic disturbance. Below we analyze the methodologies used to estimate the market power of individual banks (i.e. the dependent variable in Eq. 1).

Estimation of the competitive conditions in the banking industry has attracted the interest of many researchers over the last three decades (for a recent review see Carbo et al., 2009). Here, we primarily resort to the method proposed by Boone (2008) and applied to the banking sector by Leuvensteijn et al. (2008) and Schaeck and Cihak (2010). This method possesses some significant advantages over other estimators of bank competition, at least for our purposes. We comment on these advantages below, after providing some theoretical background for the Boone indicator.

\subsection{The Boone indicator}

In this section we briefly discuss the methodology presented in Leuvensteijn et al. (2008) and Schaeck and Cihak (2010), who use the method of Boone et al. (2005) and Boone (2008) to 
estimate market power in the banking sector. We assume that each bank $i$ in an industry (country) $c$ produces one symmetrically differentiated product $q$ at time $t$ and faces a demand $p\left(q_{i}, q_{-i}\right)=a-b q_{i}-d \sum_{j \neq i} q_{j}$

where $p$ is the price of the product $q, a$ corresponds to the size of the market, $b$ to the market elasticity of demand and $d$ captures the extent to which consumers view the different products in a market as close substitutes. For simplicity, we drop the subscripts $t$ and $c$ from the respective equations. This is a Cournot-Nash game, with the first-order condition being

$a-2 b q_{i}-d \sum_{j \neq i} q_{j}-m c_{i}=0$

If $N$ banks are present in the banking system, one obtains $N$ first-order conditions of the form

$q_{i}\left(m c_{i}\right)=\left[(2 b / d-1) a-(2 b / d+N-1) m c_{i}+\sum_{j} m c_{j}\right] /[(2 b+d(N-1))(2 b / d-1)]$.

Note, that Eq. (4) provides a relationship between output and marginal cost $m c$ of individual banks. From the profits equation $\pi_{i}=\left(p_{i}-m c_{i}\right) q_{i}$, it then follows that profits depend on marginal costs in a quadratic way. Within this framework, and if profits are defined as variable profits that exclude entry costs, a bank enters the market if profits are higher than entry costs.

In a powerful result, Boone (2008) shows that competition increases either when the products offered by different banks become closer substitutes and banks interact more aggressively (i.e. $d$ increases, assuming $d<b$ ), or when entry costs decline. Under both conditions, the performance (here profits) of more efficient banks improves. Therefore, the empirical Boone indicator is simply

$\ln \pi_{i}=a+\beta \ln m c_{i}$ 
In other words, the profits (performance) of banks with lower marginal costs (higher efficiency) are expected to increase, i.e. $\beta$ should be negative. A lower market power (higher competition), implies that the value of $\beta$ will be larger in absolute terms (more negative). Therefore, $\beta$ serves as a continuous index of market power, and is referred as the Boone indicator. For more details on these issues, see Boone et al. (2005) and Boone (2008).

There are three advantages of this approach over the price-cost margin (Lerner index), which until recently was the method more often employed to study market power in banking. First, the price-cost margin is criticized for not being able to capture the degree of product substitutability (Vives 2008). Second, theoretical foundations of the price-cost margin as a measure of competition are not robust. In fact, a number of studies present models where higher competition leads to higher price-cost margins (for a review, see Boone, 2008).

Finally, and presumably more important for our purposes, the Lerner index may be thought of as measuring not only bank competition, but also the strength of the profitmaximizing incentives of banks. Especially in developing and transition countries (many of which are included in our sample) many banks may often have incentives that diverge widely from pure profit maximization and, subsequently, they are rather inefficient. In this case, low efficiency (high marginal cost) leads to low price-cost margins, which will misleadingly suggest a competitive situation. Moreover, in the process of liberalization, an increase in the profitmaximizing behavior of banks will reflect a higher Lerner index, which is not necessarily associated with higher market power. In contrast, under the theoretical underpinnings of the Boone indicator, both the changing of a bank's objectives (i.e. more focus on profits, efficiency and substitutability of products instead of pricing) and the changing of the competitors' focus are an integral part of the model and its solution. Compared to the Lerner index, the key here is that 
competitors' behavior also changes, i.e. they become more (less) aggressive as competition increases (decreases), and that profits are accounted for. Therefore, an increase (decrease) in the absolute value of $\beta$ is clearly and purely associated with higher (lower) competition.

Besides the Boone indicator and the Lerner index, market power in the banking industry is often measured by the H-statistic developed by Panzar and Rosse (1987) or various concentration measures. The main drawback of the H-statistic, at least for the purpose of this study, is that it does not map as robustly into a range of non-competitive conditions. Therefore, it has limited use as a continuous measure of competition (see e.g., Shaffer, 2004). In turn, concentration ratios (or the Herfindahl-Hirschman index) have been shown to provide a poor approximation of the competitive conditions in the banking industry (see e.g. Claessens and Laeven, 2004; Schaeck and Cihak, 2010). In any case, we do employ below the Lerner index and a 3-bank concentration ratio to gain some further insights into our empirical results.

\subsection{Estimating the Boone indicator at the bank-level}

Estimation of Eq. (5) requires data on marginal cost, which is generally not available. Leuvensteijn et al. (2008) estimate marginal cost at the industry level and Schaeck and Cihak (2010) use data on average cost. Both studies obtain an estimate of the competitive conditions prevailing at the country level. Here, we differentiate from these studies in two ways. First, we opt for estimating market power at the bank level, because there may be wide differences across the market power of banks within the same country. This 3-way panel-dataset setup (banks, countries, time) greatly increases the explanatory power of our empirical investigation (our dependent variable will be available at the bank level) and helps minimizing concerns about potential identification problems. 
Second, we relax the assumption of a constant marginal cost, $m c$, across all banks in the industry and we estimate it for each bank in the sample, thus deviating from the majority of previous literature on the estimation of both the Boone indicator and the Lerner index. In fact, Delis and Tsionas (2009) and Koetter and Poghosyan (2009) show that relaxing this assumption when estimating the Lerner index is highly important to ensure a minimum level of robustness of market power estimates. Also, the theoretical derivations of Boone (2008) summarized above, suggest that banks have different marginal costs $m c_{i}$. Thus, our modeling choice is in fact closer to the theoretical priors. We view both these extensions as particularly important for our study.

We estimate marginal cost using the following linear cost function $\ln c_{i t}=a_{0}+a_{1} \ln q_{i t}+a_{2} \ln d_{i t}+a_{3} \ln w_{i t}+e_{i t}$

where $c$ is the total cost of bank $i$ at time $t, q$ is bank output, $d$ is the value of bank deposits, $w$ are the prices of inputs and $e$ is a stochastic disturbance. From Eq. (6), the marginal cost of bank output is simply $\partial c_{i t} / \partial q_{i t}$. Hence, in order to obtain observation-specific estimates of the marginal cost, we need to obtain observation-specific estimates of $\partial c_{i t} / \partial q_{i t}$. This is accomplished by drawing on a non-parametric estimation technique to estimate Eq. (6), in particular the local regression (LR) technique as put forth by Cleveland and Devlin (1988). Bank-level estimates for all of the as (and thus of $a_{1}$ ) are obtained through localization of the parameters. This methodology has been implemented by Delis and Tsionas (2009). More details both on the LR methodology and the estimation procedure are provided in Appendix A.

Estimation of Eq. (6) using the aforementioned technique presents some considerable advantages, besides the obvious one of deriving observation-specific estimates of the marginal cost (which is not possible using parametric methods). First, the non-parametric nature of the method implies that no assumption regarding the functional form of the underlying production 
relationship (and thus the cost function) is made globally, and it is well-known that it is quite difficult for the researcher to be certain that the "correct" functional form has been chosen. Therefore, choosing for example between the Cobb-Douglas, the translog or any other cost function is not an issue. ${ }^{1}$ Second, and given this qualification, economic hypotheses are not rejected simply because an "improper" functional form has been chosen. Third, localization implies that, besides obtaining bank-level marginal costs, bank-level elasticities of cost with respect to deposits and input prices are also obtained, which may be quite useful information for managers and policy-makers. In particular, banks may have market power in deposits, which can also be calculated on the basis of another indicator on deposit rates and $a_{2}$. Last, but not least, the fact that LR (or any other local method) allows for observation-specific parameter estimates suggests a plausible approach to identify parameter heterogeneity, which may be of great importance in indicating individual bank strategies. For more on these issues, see Kumbhakar et al. (2007).

Data for the bank variables are taken from BankScope. In terms of the time span of the database we go as far back as possible for each country, taking into account concerns associated with coverage and accounting issues. Therefore, we have bank data to cover all countries for which information on the country-specific variables (discussed in the following section) is available, yet the starting point is different for each country. ${ }^{2}$ All data are reported in euros and are expressed in constant prices where appropriate. We limit the empirical analysis to the unconsolidated statements of commercial banks, in order to reduce the possibility of introducing

\footnotetext{
${ }^{1}$ In fact, we have experimented with the translog cost function and we obtained very similar results (within a 5 per cent range).

${ }^{2}$ We have contacted Bankscope on this front to verify that the definitions for the variables used are comparable across countries. Also, the suggestion was not to include data before 1987 for any country owing to differences in accounting standards. The same approach is undertaken by the study of Beck and Demirguc-Kunt (2009), who construct databases on similar variables on behalf of the World Bank.
} 
aggregation bias in the results. Only banks with at least three sequential observations are included in the sample. Also, the data were reviewed for outliers or other inconsistencies (zero or negative values for e.g. assets or deposits) and some observations are excluded accordingly. We end up with a large unbalanced panel dataset that consists of 84,768 observations. This dataset covers approximately $81 \%$ of the total banking assets in the countries examined. Detailed information on the dataset (on a country-specific basis) is provided in Appendix B.

Since it is not possible to consider the hundreds of products that banks offer simultaneously, modeling banking production requires aggregating outputs and inputs. To define inputs and outputs of banks we use the intermediation approach, where three inputs, namely labor, physical capital and deposits are used to produce earning assets (for details, see Berger and Humphrey, 1997 and for a similar implementation, see e.g. Brissimis et al., 2008; Berger et al., 2009). In particular, bank costs (c) are measured by real total expenses of bank $i$ at time $t$. Bank output $(q)$ is proxied by the real total earning assets, which include loans, securities and other earning assets (such as derivatives, investments and insurance assets). $d$ stands for real total deposits and short-term funding. Two input prices are considered, the first $\left(w_{1}\right)$ representing the price of labor (measured by the ratio of personnel expenses to total assets) ${ }^{3}$ and the second $\left(w_{2}\right)$ the price of physical capital (proxied by the ratio of total depreciation and other capital expenses to total fixed assets). All these variables were carefully reviewed for inconsistencies owing to changes in accounting schemes over the sample period (descriptive statistics are reported in Appendix B). In addition, we examine the sensitivity of our results by controlling for credit risk (using the ratio of non-performing loans to total loans). Changes in the results are not significant;

\footnotetext{
${ }^{3}$ We divide personnel expenses by total assets because the Bankscope database lacks data for the number of bank employees for many banks. A similar approach has been followed by many other relevant papers (see e.g. Altunbas et al., 2001; Claessens and Laeven, 2004).
} 
however, this measure was not available for many of the banks in the early years of our sample and, therefore, we report the results of the model without credit risk.

\subsection{Estimates of bank market power}

Estimation of Eq. (6) and, subsequently of Eq. (5) is carried out for the full sample, since (i) the Boone indicator does not need defining the market boundaries (Boone, 2008) and (ii) bank-level (and thus also country-level) heterogeneity is accounted for by the local technique. ${ }^{4}$ We report average estimates for the Boone indicator on a country- and time-specific basis in Table 1 . These values are effectively a new index of banking-sector competition, which to our knowledge has the largest country and time coverage compared to other studies of bank competition in the world (see e.g. Bikker and Spierdijk, 2008). For expositional brevity, values on the Boone indicator are multiplied by 10 . Note that the values reported are directly comparable between countries, given the properties of the indicator and the estimation methodology.

The overall picture emerging from the average scores of market power for the countries examined is mixed. In Figure 1 we show the trend in banking sector competition over time, by plotting average market power estimates across (i) all countries, (ii) high-income countries, (iii) transition countries and (iv) lower-middle and low-income countries. The categorization of countries is made by the World Bank. Overall, bank competition in the world steadily increases in the period 1993-2002, but it somewhat rebounds from 2003 onwards. However, the different country groups exhibit very different trends. In high-income countries, market power of banks is on average low and stable up to 2002 , but it starts increasing thereafter. This finding is in line

\footnotetext{
${ }^{4}$ Various other sensitivity analyses were carried out, including use of time or country dummy variables, use of only one input price and estimating the cost function separately for each country. Changes in the results were not statistically significant, thus confirming the power of the local regression method (see also Delis and Tsionas, 2009).
} 
with Bikker and Spierdijk (2008), who use the H-statistic to study changes of bank competition in the world. The authors attribute the initial increase in competition to the introduction of the euro, and the subsequent decrease to the reduced traditional intermediation of banks and associated increase in debt financing and other non-traditional activities. Yet, a special role to the upward trend towards the end of the sample period can be given to the somewhat deteriorating institutions in high-income countries, as reflected in the values of the institutional variables.

In transition countries the trend is rather different. Market power of banks peaks in 1993 (2-3 years after the initiation of the transition period) and gradually declines only after 1996 . We may attribute this decline to the improved financial liberalization and the gradual penetration of foreign banks in these markets. However, the low quality of institutions may be accountable for the initial upward trend and the 5-6 year delay in observing any significant decline in bank market power. Finally, in the lower-middle and low-income countries the market power of banks seems to be fairly stable, but higher than that observed in high-income countries. This may again be attributed to the quality of institutions or to the increased risk premium observed in countries with less stable macroeconomic environment. In the following section we explore the specific potential determinants of bank market power, emphasizing the role of financial liberalization and institutions.

\section{Determinants of bank competition}

We examine the determinants of bank competition using a large panel dataset that includes as many countries and years as possible. Below we discuss the specific determinants of competition and the associated variables employed. 


\subsection{Financial liberalization}

We measure financial liberalization by employing the financial reforms index of Abiad et al. (2008). This index covers 91 countries in total over the period 1973-2005, whereas previous indices (e.g. that of Kaminsky and Schmuckler, 2003, or the European Bank for Reconstruction and Development [EBRD] index of banking sector reform) have smaller coverage in terms of years and/or countries. This makes our study the first to explore the banking competitionfinancial reform nexus at such large scale. Where the datasets coincide, the correlation between the three different indices is very high (the correlation of the Abiad et al. index is 0.85 with the Kaminsky-Schmuckler and 0.88 with the EBRD indicator, respectively). The financial reforms index covers a wide array of reform processes and is directly comparable across countries.

More specifically, Abiad et al. (2010) construct a composite indicator that includes seven pillars. Each pillar receives a score on the basis of whether the financial sector is liberalized or not. The seven pillars are as follows (range of scores in parentheses): credit controls and reserve requirements (0-4), aggregate credit ceilings (0-1), interest rate liberalization (0-4), banking sector entry (0-5), capital account transactions (0-3), privatization (0-3), securities markets (0-5) and banking sector supervision (0-6). Therefore, this index can take values from 0 to 31 . In general, low scores indicate repressed financial sectors and high scores liberalized financial sectors. ${ }^{5}$ As the index principally quantifies reforms in the banking sector, we use the terms "financial" and "banking" reform interchangeably. The average value for the financial reforms index for each country is reported in Appendix B.

\footnotetext{
${ }^{5}$ For the last pillar (banking supervision) a high score indicates high regulation and a low score an unregulated financial sector. Note that a high score for this pillar implies that the country has reformed the banking sector so that (i) a capital adequacy ratio is adopted, (ii) the banking supervisory agency is independent from executives' influence, (iii) the banking supervisory agency conducts effective supervision through on-site and off-site examinations, and (iv) the banking supervisory agency covers all financial institutions without exception. This kind of regulation is considered as a "positive" reform (re-regulation) aiming to enhance financial stability mainly through the introduction of safety nets. Therefore, the value of this sub-index is added to the general score.
} 


\subsection{Institutional environment}

The variables $I E$ in Eq. (1) correspond to a number of indices that assess institutional strength in the countries examined. We use three indices obtained from the International Country Risk Guide (ICRG) to proxy (i) transparency (inverse of corruption) within the political system (denoted as transparency), (ii) the quality of the judicial system and popular observance of law (law quality), and (iii) the quality of bureaucracy (bureaucratic quality). Higher values for these indices reflect higher institutional quality. The variables transparency and law quality take values between 0 and 6 (inclusive) and the variable bureaucratic quality between 0 and 4 . Among the various databases including information on the institutional environment, the ICRG is the one with the best coverage. Still, for 7 countries covered by the Abiad et al. (2010) database, the ICRG does not include information. Thus, our final sample includes 84 countries. Appendix B reports country-specific averages for the institutional variables.

The most common form of corruption, which is also relevant for our purposes, is financial corruption in the form of demands for special payments and bribes connected with all sorts of transactions. Such corruption usually makes markets less efficient and generates networking effects that could lead, inter alia, to anticompetitive behavior. Our measure accounts for various forms of corruption, such as excessive patronage, nepotism, job reservations, 'favorfor-favors', secret party funding, and suspiciously close ties between politics and business. As a result, we expect that in countries with high corruption (low transparency) competitive conditions are lower, and these effects may be more pronounced for large banks with higher political power. 
The variable law quality, in turn, is an assessment of the strength and impartiality of the legal system, as well as of popular observance of law. Therefore, a country can enjoy a high rating in terms of the quality of the judicial system, but a low rating if enforcement is inferior. These characteristics of the index are relevant for bank competition, because they reflect the ability of policy authorities to (i) identify various forms of anticompetitive conduct in banking and (ii) impose sanctions. Finally, the institutional strength and quality of bureaucracy tends to minimize policy discontinuity when governments change, to enhance the state's role in identifying non-competitive conduct, and to safeguard the regulatory environment in an efficient way. Hence, both law quality and bureaucratic quality are expected to have a positive impact on bank competition. Again, these effects may be non-uniform across banks in the sample, as the impact of the institutional variables on bank market power may be reinforced by bank characteristics like size and access to capital. We will investigate this issue in our empirical analysis below.

\subsection{Control variables}

In Eq. (1) we control for a number of bank-specific and macroeconomic variables that may affect the market power of banks. In particular, we use the ratio of equity capital to total assets (capitalization) to control for bank capitalization and the natural logarithm of real total assets (bank size) to proxy bank size. ${ }^{6}$ Well-capitalized and larger banks are probably able to set higher margins or have access to cheaper source of funds due to scale economies, informational

\footnotetext{
${ }^{6}$ We have additionally experimented with measures of bank liquidity (measured by the ratio of liquid assets to total assets) and credit risk (measured either by the ratio of non-performing loans to total loans or the ratio of loan loss provisions to total loans). However, we did not find significant changes in the results on our main variables. At the same time, the sample is greatly reduced when including the aforementioned variables, owing to missing data in the early years of our sample period. Especially for liquidity there are concerns about the direct comparability of the data between countries.
} 
asymmetries and moral hazard issues. Also, as discussed above, larger banks could impound the otherwise effective role of institutions in enhancing competition. However, in relatively competitive markets, or in banking systems were efficient tacit collusion is in place, we do not expect these effects to be present. Data for these variables are obtained from Bankscope and country averages are reported in Appendix B.

Concentration has been considered in the past as a measure of competition, but there is now consensus that it does not directly gauge banks' competitive behavior (Claessens, 2010) and can be better viewed as a determinant of competition (Bikker and Haaf, 2002). Information on this variable is obtained from Beck and Demirguc-Kunt (2009), who also obtain bank-level data from Bankscope. Existing evidence on the relationship between concentration and competition is mixed, with some studies reporting a positive relationship (e.g. Bikker and Haaf, 2002) and other studies an insignificant one (e.g. Yeyati and Micco, 2007). Again, differences in the findings can be attributed to the institutional environment within which banks operate, along with the characteristics of the market. Thus, in countries with strong institutions and robust competition policies, a high concentration may not be associated with anticompetitive conduct. We provide further insights on this issue in the empirical analysis below.

Finally, we control for the impact of the macroeconomic environment common to all banks in terms of (i) economic development (by including the natural logarithm of GDP per capita, gdp per capita), (ii) the state of the economy (using growth in GDP, GDP growth), and (iii) stability in the monetary conditions (by including the consumer price index, inflation). These macroeconomic variables are obtained from the World Development Indicators. Ideally, one may also want to control for elements like stock market capitalization, the importance of banking in 
financing economic activity, etc. However, the present analysis is constrained by the availability of data for the early years of our dataset.

\section{Empirical methodology and estimation results}

\subsection{Identification issues}

Two econometric concerns of the regressions of bank market power may be the dynamic nature of bank competition, and the potential endogeneity of some of the right-hand side variables. Concerning the former, Berger et al. (2000), among others, suggest that even developed banking systems may be characterized by informational opacity, networking, and relationship-lending. All these elements will cause bank rents and market power to persist. To account for this type of persistence in our econometric model, we include the lagged dependent variable among the regressors. Estimation is carried out using the system GMM estimator for dynamic panels put forth by Blundell and Bond (1998). Besides accounting for the specified dynamics, the latter estimator has two additional virtues. First, it does not break down in the presence of unit roots (for a proof see Binder et al., 2003); and, second, it accommodates the possible endogeneity between market power and some of the independent variables by means of appropriate instruments. In general, a value of the coefficient on the lagged dependent variable statistically equal to 0 implies that bank market power is characterized by high speed of adjustment, while a value statistically equal to 1 means that the adjustment is very slow. Values between 0 and 1 suggest that market power persists, but will eventually return to a normal (average) level. Finally, this coefficient takes implausible (negative) values if convergence to 
equilibrium cannot be achieved, which probably indicates a problem with the dataset (e.g., very small time dimension of the panel). ${ }^{7}$

The financial reforms index, the institutional variables and the bank-level variables should be considered as endogenous determinants of market power. Concerning the former, banks usually perceive financial reform and foreign bank entry as bound to happen once these begin, which triggers a situation of self-fulfilling expectations. Under this assumption, banks will price their products, and reform their risk-taking activities and associated capital levels in light of the forthcoming developments in the banking sector. Or it could be that banks with market power may even exacerbate changes that serve their own interest (especially if institutions are weak within a political-capitalism regime). Also, it is quite important to note that bank size is a key element through which financial reforms may affect the market power of banks. In particular, financial reforms aiming at liberalizing credit controls, interest rates and capital account transactions will first be adopted by the leading banks in the market. On the same line, banking sector entry is bound to be affected by the policies of the largest players in the market, especially if institutions and official supervisory power are rather weak. This is because larger banks usually have better access to equity capital markets, which poses (monopoly) entry restrictions to newcomers. ${ }^{8}$

Given the above theoretical considerations, it could hold that the effect of financial liberalization differs with bank characteristics, such as size and capitalization. Therefore, besides exploring the direct effect of financial reforms on bank market power, we additionally adopt an identification strategy that involves the interaction of the financial reforms index with bank characteristics. In other words, even if it is hard to argue convincingly that the level effect of

\footnotetext{
${ }^{7}$ For more on these issues, see Nerlove (2002).

${ }^{8}$ This discussion is in line with the theoretical models of Laffont (for a review, see Estache and Wren-Lewis, 2009).
} 
reform on competition is causal, a significant interaction term between reforms and bank characteristics would be hard to explain other than through a causal effect.

The above line of reasoning is also valid for the institutional variables. In particular, the effects of institutions on bank market power could be reinforced by bank size or better access to cheaper sources of capital. A difference here is that the institutional variables are most probably viewed by banks as predetermined. In general, banks observe the level of institutional strength and ownership in the previous period and set their interest-rate, capital and risk levels accordingly. This implies that a change in institutions today will affect, to the very best, market power of banks in the next period. Therefore, the institutional variables enter Eq. (1) lagged once, again easing concerns regarding possible endogeneity of these variables.

In terms of the Blundell and Bond (1998) method, the above arguments imply that the variables entering the equation lagged once serve as exogenous variables, while the bank-level variables and the financial reforms index are strictly endogenous. In line with Bond (2002), this implies using only the second and third lags of the market power, bank-level and financialreforms variables as instruments. In contrast, the first lag of the institutional variables also serves as valid instrument (in addition to the second and third lags of these variables). Bearing these issues in mind we now turn to the discussion of our empirical results.

\subsection{Direct identification}

Table 2, Panel A reports the estimation results when the identification strategy does not involve interactions with bank characteristics. All specifications include country-specific time effects. The Sargan test shows that estimated equations are not overidentified. Even though some of the equations indicate that first-order autocorrelation (AR1) is present, this does not indicate 
that the estimates are inconsistent. Inconsistency would be implied if second-order autocorrelation was present (Blundell and Bond, 1998), but this case is rejected by the test for AR2 errors. The values of the coefficients on the lagged dependent variable indicate persistence of bank market power to a moderate extent. Higher values are observed in low-income countries (see column 4) and this is a first indication of the relative opaqueness and rigidity of the banking systems in less developed countries.

The first three specifications in Table 2 report the direct impact of financial reform and institutions on bank market power for the full sample. In column (3) we use an IV method, instead of GMM. The results in all three equations show that financial reforms lower market power of banks, and so do quality institutions. This is a first indication that reforms and institutions matter in shaping the competitive conditions in the banking sector. Therefore, so far the results favor both lines of argument as set out in the introduction of the paper. On the one hand, financial liberalization is essential in shaping the competitive conditions in the banking sector and, on the other, institutions are equally important.

The effect of the rest of the control variables is in line with expectations. Larger and wellcapitalized banks are usually those possessing higher market power. This is intuitive, because these banks have access to cheaper sources of finance, cope better with moral hazard issues on the part of borrowers, and are sometimes able to impound institutions and competition policy or lead privatizations and M\&As to monopoly outcomes. The impact of concentration on bank market power is positive, but statistically insignificant at the 5\% level. This shows that concentration is generally uncorrelated with bank market power (a finding in line with Claessens and Laeven, 2004). It remains to examine whether this holds for different groups of countries. The picture shown in Figure 1 is confirmed by the regressions, with banks in less developed 
countries possessing higher market power. Growth does not seem to play an important role in shaping competitive conditions in the banking sector, while in countries with high inflation market power of banks rises.

In columns (4) and (5) of Panel A we examine whether results are different when splitting the sample into high- and low-income countries (the low-income group also includes the countries described as "lower-middle income"). The results on the financial reform variable are modified and show that, while reforms continue to exert a negative and significant impact on bank market power in the high-income countries, the respective impact in the low-income group turns insignificant at conventional levels. In contrast, the impact of the institutional variables remains negative for both subgroups. This shows that quality institutions contain market power of banks, irrespective of the level of economic development. Another notable difference between the results of regressions in columns (4) and (5) is that concentration has a positive effect on market power only in low-income countries. This is an interesting finding, as it implies that M\&A activity where institutions are relatively weak may lead to monopoly outcomes. On the contrary, a higher concentration ratio in well-developed countries does not imply a significantly higher market power of banks. This finding is consistent with the results of Demirguc-Kunt et al. (2004), who suggest that concentration has a negative effect on banking system efficiency, except in rich countries with well-developed financial systems and higher economic freedoms.

In column (6) we present the effect of the interaction of financial reforms with institutions on bank market power. Thus, we introduce multiplicative terms of all the institutional and the GDP per capita variables with the financial reforms index, and using the full sample. Given that the correlation between the level and the multiplicative terms is very high (i.e. an indication of multicollinearity) we mean-center the variables (i.e. we generate new variables by 
subtracting their means). The results show that merely all the interaction terms enter the estimated equation with a negative and statistically significant coefficient. This implies that in those countries identified with low-quality institutions and subordinate economic development, the market power of banks is higher. Therefore, the theoretical literature highlighting the importance of proper institutions as a prerequisite of reforms in general, and financial liberalization in particular, is confirmed (Tirole, 1991; Stazinskis, 1991; Eyal et al., 1998). It remains to examine whether these results are validated when we choose a different identification scheme.

\subsection{Identification through bank characteristics}

In Table 2, Panel B we report the results when identification is made through bank characteristics. Again, we mean-center the respective variables to reduce the impact of multicollinearity. In general, the findings reinforce the conclusions of Section 4.2. Financial reforms and institutional quality are negatively correlated with market power of banks when the full sample is used (column 1 of Panel B) and these results carry through in both the low- and the high-income countries. The impact of the rest of the control variables also remains practically unchanged.

The most important results reported in Panel B are those on the interaction terms between bank characteristics and the financial reforms and institutional variables. In particular, the negative effect of financial reforms and institutions on bank market power is higher for larger banks. This implies that financial reforms and quality institutions reduce disproportionately the market power of larger banks, which are the ones that usually posses market power (as also reflected in the positive and significant coefficient on the bank size variable). Note, however, 
that the distributional effect of financial reforms through bank size for the low-income country group (column 2 of Panel B) is less significant (only at the $10 \%$ level), while the distributional effect of the institutional variables through bank size is clearly more important in reducing market power. Taken together, these findings provide another indication that financial reforms partially fail to materialize in enhanced competitive conditions where institutions are weak. Finally, it seems that financial reforms and transparency play an important role in reducing market power when the distributional effect concerns the capitalization variable. This is intuitive because liberalization policies in the financial markets, first and foremost, widen the access to capital markets by reducing credit ceilings and enhancing capital account transactions. In turn, these policies provide access to cheaper sources of capital for all banks in the industry. In contrast, the coefficients on the interaction terms of law and bureaucratic quality with bank capitalization are statistically insignificant.

\subsection{Other sensitivity analysis}

As a final exercise, we use the Lerner index, $L_{i t c}=\left(p_{i t c}-m c_{i t c}\right) / p_{i t c}$, and the 3-bank concentration ratio as dependent variables. The Lerner index is estimated at the bank level, using the local regression method described in Appendix A, and the marginal cost estimates obtained above to estimate the Boone indicator. We proxy the price of bank output $p$ (i.e. the bank-level interest rate) using the ratio of total revenue to total earning assets (for descriptive statistics, see Appendix B). This measure reflects the full array of bank outputs. ${ }^{9}$ The Lerner index has a statistically significant correlation with the Boone indicator, which is equal to 0.462 . The

\footnotetext{
${ }^{9}$ Alternatively, we employ the ratio of interest income to the value of total loans. This measure is probably more restrictive for our purpose as it essentially measures lending rates and will reflect market power only in lending, but it is also the measure favored by most of the literature (see e.g. Maudos and de Guevara, 2007).
} 
correlation between the 3-bank concentration ratio and the Boone indicator is as low as 0.009 and statistically insignificant.

The estimation results are reported in Table 3. For both measures we report equations with and without multiplicative terms on bank characteristics. The results on the Lerner index equations (columns 1-2) are in line with the results on the Boone indicator. In particular, financial reform and quality institutions seem to lower the market power of banks. When introducing interaction terms between the financial reforms index and the institutional variables, the results again show that financial reforms improve competition primarily in countries with quality institutions (these results are not reported, but are available on request). Combined with the high correlation with the Boone indicator, these findings show that the Lerner index is still a valuable indicator of market power. ${ }^{10}$

In contrast, the results on the concentration equations are qualitatively and quantitatively different. The most notable finding is that enhanced financial liberalization increases concentration. This effect can be attributed to the significant wave of mergers and acquisitions that occurred in many banking systems worldwide following the liberalization policies. In addition, this effect is lower for large and well-capitalized banks, implying that in banking sectors with relatively few large banks, financial reforms help smaller and less capitalized banks to enter the market. All in all, the results on banking industry concentration show that concentration is quite a different notion than competition, at least in the banking sector (see also Claessens and Laeven, 2004; Schaeck and Cihak, 2010).

\footnotetext{
${ }^{10}$ This analysis makes the present study the first to compare the Boone indicator estimates with the Lerner index for such an extensive panel of banks.
} 


\section{Conclusions}

In this paper we explore the determinants of bank-level market power, placing an emphasis on financial reforms and the quality of institutions. To this end, we use a panel dataset of banks from 84 countries, and we estimate market power by elaborating on the newly established method of Boone (2008). Effectively, this provides a new global index of the competitive conditions in the banking sectors. Our empirical findings confirm the importance of institutional quality, in terms of a positive relationship with bank competition. Thus, institutional endowment is vital for the enhancement of competition following a period of financial liberalization policies. In particular, transparency, the rule of law and bureaucratic quality are negatively related with bank market power; and when these suffer financial reforms partially fail to deliver more competitive conditions in the banking markets.

Evidently, well-performing and transparent legal and bureaucratic institutions in the high income countries allow market competition to emerge as a direct aftermath of sectoral liberalization of the 1980s and 1990s. In contrast, competition procrastinated when the same policies of banking liberalization were applied in relative underdeveloped countries. Thus, sectoral reform in transition economies does not produce the same efficiency gains as in developed economies until it is backed up by well-functioning institutions. These findings are robust across a number of robustness checks and identification methods. An interesting extension to this paper involves examining which of the components of the financial reforms index are the most important as competition-enhancing mechanisms. We leave this and other questions to be answered by future research. 


\section{Appendix A. The local regression method}

A thorough discussion of local regression (LR) is provided in Loader (1999); here we only provide a basic analysis. LR estimation is a consistent way to allow for nonparametric effects within the parametric model, and this is accomplished as follows. The underlying model for local regression is $Y_{i}=\mu\left(x_{i}\right)+\varepsilon_{i}$, where $x$ are predictor variables and $Y$ is the response variable. The unknown function $\mu(x)$ is assumed to be smooth and is estimated by fitting a polynomial model (a quadratic in our case, as in most of the literature) within a local sliding window. Therefore, no strong assumptions are made about $\mu$ globally, but locally around $x$ we assume that $\mu$ can be well-approximated. Note that this not a strong assumption when using large and rich datasets like the one of the present analysis. For a fitting point $x$, define a bandwidth $h$ that controls the smoothness of the fit and a smoothing window $(x-h(x), x+h(x))$. To estimate $\mu$, only observations within this sliding window are used. Therefore, for each fitting point a locally weighted least squares criterion of the following form is considered:

$$
\sum_{i=1}^{n} W\left(\frac{x_{i}-x}{h}\right)\left(Y_{i}-\left(a_{0}+a_{1}\left(x_{i}-x\right)\right)\right)^{2}
$$

where $W$ is the weight function that assigns largest weights to observations close to $x$, and takes the form

$$
W(u)= \begin{cases}\left(1-|u|^{3}\right)^{3} & \text { if }|u|<1 \\ 0 & \text { otherwise }\end{cases}
$$

The local least squares criterion of Eq. (A.1) is minimized to produce estimates $\hat{a}_{0}$ and $\hat{a}_{1}$ for each observation.

This discussion relates to the bivariate local regression. The multivariate local regression simply adds further terms to the right hand-side of the formula for $Y$ and forms accordingly the 
associated Eq. (A.1). Estimations were carried out using the program Locfit. An important issue in the implementation of LR is the choice of an optimal bandwidth. Many alternatives have been proposed, like plug-in methods and cross-validation (see Kumbhakar et al., 2007). Here we used the generalized cross-validation method (see Loader, 1999), which in our case yields a bandwidth equal to 0.701 . For other applications of local methods to bank data, see e.g. Kumbhakar et al. (2007) and Delis and Tsionas (2009). 


\section{Appendix B. Information on the dataset}

Table B1

Sample coverage and averages of country-level variables

\begin{tabular}{|c|c|c|c|c|c|c|c|c|c|c|c|c|}
\hline Country & $\begin{array}{l}\text { Income } \\
\text { and country } \\
\text { group }\end{array}$ & Sample & $\begin{array}{l}\text { No. of } \\
\text { observ. }\end{array}$ & $\begin{array}{l}\text { Financial } \\
\text { reform }\end{array}$ & $\begin{array}{l}\text { Range of } \\
\text { financial } \\
\text { reform }\end{array}$ & Corruption & $\begin{array}{l}\text { Law } \\
\text { quality }\end{array}$ & $\begin{array}{l}\text { Bureauc. } \\
\text { quality }\end{array}$ & $\begin{array}{l}\text { GDP } \\
\text { growth }\end{array}$ & Concent. & $\begin{array}{l}\text { GDP per } \\
\text { capita }\end{array}$ & Inflation \\
\hline Albania & LMI-T & $1992-2005$ & 101 & 11.64 & $3.75-18$ & 2.66 & 2.80 & 1.25 & 5.71 & 0.83 & $1,091.07$ & 30.31 \\
\hline Algeria & LMI-MENA & 1994-2005 & 147 & 10.69 & $8.5-11.25$ & 2.12 & 2.46 & 1.70 & 3.59 & 0.85 & $1,820.12$ & 8.72 \\
\hline Argentina & HMI-LA & 1989-2005 & 1,222 & 14.24 & $6-15$ & 2.92 & 3.84 & 2.50 & 2.86 & 0.45 & $7,170.30$ & 332.96 \\
\hline Australia & $\mathrm{HI}$ & $1992-2005$ & 388 & 20.21 & $17-21$ & 4.89 & 5.99 & 4.00 & 3.54 & 0.67 & $20,001.39$ & 2.44 \\
\hline Austria & $\mathrm{HI}$ & 1988-2005 & 744 & 15.22 & $7.5-19.5$ & 4.78 & 6.00 & 3.99 & 2.47 & 0.75 & $21,742.80$ & 2.29 \\
\hline Azerbaijan & LMI-T & 1992-2005 & 144 & 10.43 & $6-16$ & 1.95 & 3.96 & 1.00 & 1.91 & 0.88 & 713.40 & 297.04 \\
\hline Bangladesh & LI-E & 1992-2005 & 461 & 9.21 & $8-11$ & 1.69 & 2.22 & 1.53 & 5.13 & 0.58 & 322.63 & 5.28 \\
\hline Belarus & UMI-T & 1992-2005 & 129 & 9.64 & $5.5-11.5$ & 2.77 & 4.00 & 1.00 & 2.16 & 0.83 & $1,274.16$ & 379.46 \\
\hline Belgium & $\mathrm{HI}$ & 1988-2005 & 988 & 18.57 & $11.25-21$ & 4.26 & 5.49 & 4.00 & 2.28 & 0.77 & $20,841.10$ & 2.16 \\
\hline Bolivia & LMI-LA & 1993-2005 & 193 & 17.00 & $15-19$ & 2.60 & 2.86 & 1.61 & 3.95 & 0.52 & 997.35 & 5.68 \\
\hline Brazil & UMI-LA & 1991-2005 & 1,815 & 9.60 & $6-12$ & 3.07 & 2.62 & 2.44 & 2.64 & 0.51 & $3,630.66$ & 369.04 \\
\hline Bulgaria & UMI-T & 1991-2005 & 233 & 11.98 & $5.75-17.25$ & 3.35 & 4.43 & 2.00 & 0.71 & 0.74 & $1,611.35$ & 126.60 \\
\hline Burkina-Faso & LI-SSA & 1996-2005 & 116 & 12.60 & $10-13$ & 2.15 & 3.81 & 1.00 & 6.43 & 0.77 & 228.91 & 2.74 \\
\hline Cameroon & LMI-SSA & 1994-2005 & 162 & 11.60 & $4.75-13$ & 2.05 & 2.43 & 1.32 & 4.53 & 0.71 & 674.34 & 2.97 \\
\hline Canada & $\mathrm{HI}$ & 1988-2005 & 1,024 & 20.11 & $17-21$ & 5.67 & 6.00 & 4.00 & 2.77 & 0.54 & $21,522.28$ & 2.52 \\
\hline Chile & UMI-LA & 1988-2005 & 235 & 16.56 & $15-19$ & 3.42 & 4.65 & 2.52 & 5.96 & 0.56 & $4,309.98$ & 9.23 \\
\hline China & LMI-E & 1988-2005 & 1,417 & 4.92 & $0.75-10.25$ & 2.78 & 4.33 & 2.09 & 9.53 & 0.74 & 783.40 & 6.75 \\
\hline Colombia & LMI-LA & 1989-2005 & 422 & 12.29 & $2-15$ & 2.59 & 1.35 & 2.47 & 3.21 & 0.49 & $2,387.07$ & 17.00 \\
\hline Costa Rica & UMI-LA & 1991-2005 & 542 & 9.40 & $5-11$ & 4.31 & 4.00 & 2.03 & 4.88 & 0.73 & $3,823.85$ & 14.43 \\
\hline Czech Rep & HI-T & 1991-2005 & 192 & 15.53 & $7.75-19.25$ & 3.61 & 5.28 & 3.00 & 1.49 & 0.73 & $5,412.60$ & 9.89 \\
\hline Denmark & $\mathrm{HI}$ & $1988-2005$ & 1,147 & 19.85 & $16.25-21$ & 5.86 & 6.00 & 4.00 & 1.90 & 0.79 & $27,394.07$ & 2.40 \\
\hline Dominican Rep & LMI-LA & $1992-2005$ & 618 & 11.61 & $10.25-14.25$ & 3.07 & 3.27 & 1.40 & 5.57 & 0.65 & $2,475.83$ & 11.45 \\
\hline Ecuador & LMI-LA & 1997-2005 & 380 & 13.89 & $13-12$ & 2.87 & 3.11 & 2.00 & 3.31 & 0.65 & $1,398.40$ & 30.92 \\
\hline Egypt & LMI-MENA & 1988-2005 & 419 & 10.72 & $0-15$ & 2.28 & 3.41 & 2.00 & 4.26 & 0.66 & $1,289.22$ & 9.56 \\
\hline El Salvador & LMI-LA & $1995-2005$ & 155 & 15.91 & $13.5-16$ & 3.22 & 2.88 & 1.77 & 3.00 & 0.81 & $2,193.80$ & 4.23 \\
\hline Estonia & HI-T & 1993-2005 & 139 & 18.62 & $9.25-21$ & 3.77 & 4.00 & 2.67 & 5.30 & 0.91 & $4,064.01$ & 17.94 \\
\hline Finland & $\mathrm{HI}$ & 1988-2005 & 594 & 16.47 & $15-17$ & 6.00 & 3.84 & 3.97 & 2.44 & 0.95 & $21,315.59$ & 2.36 \\
\hline
\end{tabular}




\begin{tabular}{|c|c|c|c|c|c|c|c|c|c|c|c|c|}
\hline France & $\mathrm{HI}$ & $1987-2005$ & 1,304 & 19.37 & $16-21$ & 4.27 & 6.00 & 3.72 & 2.22 & 0.59 & $20,163.36$ & 2.09 \\
\hline Germany & $\mathrm{HI}$ & 1991-2005 & 9855 & 18.73 & $17-19$ & 4.96 & 5.54 & 4.00 & 1.61 & 0.61 & $22,028.15$ & 2.00 \\
\hline Ghana & LI-SSA & $1995-2005$ & 132 & 9.55 & $7-12$ & 2.50 & 2.45 & 2.23 & 4.63 & 0.89 & 257.51 & 26.21 \\
\hline Greece & HI & $1988-2005$ & 485 & 14.39 & $5.75-18$ & 4.43 & 4.04 & 2.84 & 2.93 & 0.86 & $10,957.88$ & 8.81 \\
\hline Guatemala & LMI-LA & $1992-2005$ & 380 & 13.21 & $8-16$ & 2.65 & 2.23 & 1.42 & 3.76 & 0.34 & $1,655.83$ & 8.30 \\
\hline Hong Kong & HI-E & $1992-2005$ & 443 & 19.36 & $18-20$ & 4.07 & 4.96 & 3.09 & 3.93 & 0.62 & $25,110.35$ & 2.63 \\
\hline Hungary & HI-T & $1990-2005$ & 275 & 15.73 & $7.5-20.25$ & 4.36 & 4.95 & 3.51 & 1.67 & 0.69 & $4,443.23$ & 16.32 \\
\hline India & LMI-E & 1992-2005 & 898 & 9.36 & $3-13$ & 2.57 & 3.89 & 3.00 & 6.33 & 0.36 & 435.05 & 6.90 \\
\hline Indonesia & LMI-E & $1990-2005$ & 957 & 12.19 & $11-14$ & 1.79 & 2.98 & 1.84 & 4.81 & 0.55 & 804.86 & 12.24 \\
\hline Ireland & $\mathrm{HI}$ & $1992-2005$ & 506 & 20.86 & $19-21$ & 3.68 & 5.83 & 4.00 & 6.95 & 0.65 & $22,332.49$ & 3.05 \\
\hline Israel & $\mathrm{HI}$ & 1990-2005 & 182 & 16.00 & $11-19$ & 3.98 & 4.58 & 3.79 & 4.72 & 0.78 & $17,947.44$ & 7.62 \\
\hline Italy & $\mathrm{HI}$ & $1987-2005$ & 1,498 & 15.95 & $9-20$ & 3.33 & 5.07 & 3.05 & 1.75 & 0.60 & $17,813.22$ & 3.79 \\
\hline Jamaica & UMI-LA & $2002-2005$ & 33 & 15.00 & $15-15$ & 1.60 & 1.53 & 3.00 & 2.11 & 0.82 & $3,668.20$ & 11.58 \\
\hline Japan & $\mathrm{HI}$ & $1988-2005$ & 9,238 & 16.39 & $12-18$ & 4.10 & 5.42 & 3.98 & 2.02 & 0.38 & $35,510.57$ & 0.68 \\
\hline Jordan & LMI-MENA & $1992-2005$ & 165 & 17.55 & $14.75-19.25$ & 3.51 & 4.20 & 2.22 & 5.89 & 0.88 & $1,790.81$ & 2.80 \\
\hline Kazakhstan & UMI-T & 1996-2005 & 158 & 12.78 & $11.25-13$ & 1.94 & 4.00 & 2.00 & 6.47 & 0.66 & $1,394.28$ & 12.03 \\
\hline Kenya & LI-SSA & 1992-2005 & 402 & 12.64 & $7.5-15.5$ & 2.48 & 2.68 & 2.40 & 2.55 & 0.60 & 411.60 & 13.27 \\
\hline Korea & HI-E & 1991-2005 & 398 & 14.80 & $14-15$ & 3.65 & 4.42 & 3.19 & 5.63 & 0.36 & $10,549.78$ & 4.52 \\
\hline Latvia & UMI-T & 1992-2005 & 315 & 17.89 & $6.5-21$ & 2.40 & 4.89 & 2.33 & 2.40 & 0.53 & $3,214.09$ & 33.50 \\
\hline Lithuania & UMI-T & $1992-2005$ & 112 & 14.95 & $3.75-19.25$ & 2.70 & 4.00 & 2.33 & 1.16 & 0.80 & $3,350.89$ & 113.37 \\
\hline Madagascar & LI-SSA & 1994-2005 & 88 & 14.56 & $10.75-16.25$ & 3.97 & 2.73 & 1.00 & 2.82 & 0.79 & 244.75 & 16.19 \\
\hline Malaysia & UMI-E & 1993-2005 & 612 & 15.08 & $16-17$ & 3.26 & 3.98 & 2.77 & 5.98 & 0.43 & $3,915.04$ & 2.70 \\
\hline Mexico & UMI-LA & 1989-2005 & 719 & 16.47 & $10-20$ & 2.66 & 2.67 & 2.50 & 3.17 & 0.67 & $5,453.37$ & 15.19 \\
\hline Morocco & LMI-MENA & 1992-2005 & 116 & 12.36 & $5-14$ & 2.96 & 5.48 & 2.00 & 3.10 & 0.64 & $1,293.17$ & 2.76 \\
\hline Mozambique & LI-SSA & 1996-2005 & 105 & 14.40 & $11.5-15$ & 2.63 & 3.00 & 0.68 & 8.06 & 0.81 & 249.37 & 13.20 \\
\hline Netherlands & HI & 1988-2005 & 752 & 20.00 & $19-21$ & 5.77 & 6.00 & 4.00 & 2.80 & 0.72 & $21,611.85$ & 2.28 \\
\hline New Zealand & $\mathrm{HI}$ & 1996-2005 & 122 & 20.00 & $20-20$ & 5.26 & 5.95 & 4.00 & 3.30 & 0.78 & $13,482.41$ & 1.96 \\
\hline Nicaragua & LMI-LA & 1992-2005 & 131 & 11.93 & $2.5-15.25$ & 3.94 & 3.60 & 1.00 & 3.08 & 0.63 & 741.59 & 6.70 \\
\hline Nigeria & LI-SSA & $1992-2005$ & 488 & 14.27 & $10.75-17$ & 1.49 & 2.55 & 1.26 & 3.86 & 0.53 & 376.39 & 26.54 \\
\hline Norway & HI & 1989-2005 & 490 & 17.37 & $16.25-18.25$ & 5.44 & 6.00 & 3.84 & 3.01 & 0.90 & $34,099.23$ & 2.40 \\
\hline Pakistan & LI-MENA & $1992-2005$ & 428 & 9.79 & $6-12$ & 2.02 & 2.90 & 2.00 & 4.26 & 0.62 & 531.82 & 7.61 \\
\hline Paraguay & LMI-LA & $1992-2005$ & 316 & 15.29 & $12.5-16.5$ & 1.79 & 3.23 & 1.39 & 2.04 & 0.45 & $1,392.55$ & 11.04 \\
\hline Peru & LMI-LA & $1992-2005$ & 320 & 17.95 & $12.25-19$ & 2.87 & 2.85 & 1.60 & 4.24 & 0.66 & $2,008.64$ & 14.38 \\
\hline
\end{tabular}




\begin{tabular}{|c|c|c|c|c|c|c|c|c|c|c|c|c|}
\hline Philippines & LMI-E & $1990-2005$ & 566 & 14.55 & $9.5-17$ & 2.54 & 2.79 & 1.98 & 3.52 & 0.79 & 947.79 & 7.55 \\
\hline Poland & UMI-T & $1992-2005$ & 421 & 15.38 & $9.75-18.5$ & 3.75 & 4.80 & 3.06 & 4.37 & 0.60 & $4,072.51$ & 15.81 \\
\hline Portugal & HI & $1988-2005$ & 640 & 15.47 & $10.75-17.5$ & 4.62 & 5.13 & 2.84 & 2.85 & 0.70 & $9,782.79$ & 5.58 \\
\hline Romania & UMI-T & 1997-2005 & 214 & 15.36 & $13.25-18.5$ & 2.68 & 4.23 & 1.00 & 2.06 & 0.70 & $1,853.74$ & 44.28 \\
\hline Russia & UMI-T & 1993-2005 & 5,645 & 14.83 & $9.5-17$ & 1.93 & 3.46 & 1.35 & 1.10 & 0.43 & $1,844.13$ & 126.99 \\
\hline Senegal & LI-SSA & 1993-2005 & 135 & 13.08 & $11-15$ & 2.85 & 2.82 & 1.35 & 3.90 & 0.74 & 467.68 & 4.16 \\
\hline Singapore & HI-E & 1991-2005 & 181 & 18.40 & $17-20$ & 4.14 & 5.59 & 3.78 & 6.57 & 0.83 & $20,782.22$ & 1.37 \\
\hline South Africa & UMI-SSA & 1991-2005 & 454 & 16.32 & $11.25-18.25$ & 3.78 & 2.50 & 2.78 & 2.52 & 0.89 & $3,059.12$ & 7.44 \\
\hline Spain & $\mathrm{HI}$ & $1988-2005$ & 1725 & 19.14 & $14.5-21$ & 4.15 & 4.76 & 3.26 & 3.23 & 0.73 & $13,002.83$ & 4.08 \\
\hline Sri Lanka & LMI-E & $1992-2005$ & 244 & 12.36 & $9.25-15$ & 3.35 & 2.95 & 2.00 & 4.83 & 0.72 & 804.70 & 9.59 \\
\hline Sweden & $\mathrm{HI}$ & $1988-2005$ & 710 & 19.67 & $18-20$ & 5.83 & 6.00 & 4.00 & 2.20 & 0.92 & $25,479.29$ & 2.97 \\
\hline Switzerland & $\mathrm{HI}$ & $1988-2005$ & 5,464 & 19.06 & $18-20$ & 5.35 & 5.77 & 4.00 & 1.60 & 0.86 & $33,408.86$ & 1.90 \\
\hline Tanzania & LI-SSA & 2004-2005 & 35 & 17.00 & $17-17$ & 2.00 & 5.00 & 1.00 & 7.05 & 0.61 & 323.41 & 4.89 \\
\hline Thailand & LMI-E & $1988-2005$ & 519 & 12.36 & $6.25-13$ & 2.46 & 4.34 & 2.77 & 6.03 & 0.58 & $1,848.34$ & 3.99 \\
\hline Tunisia & LMI-MENA & $1992-2005$ & 185 & 12.54 & $4.75-15$ & 2.71 & 4.75 & 2.00 & 4.70 & 0.48 & $1,939.38$ & 3.57 \\
\hline Turkey & UMI-MENA & $1988-2005$ & 594 & 13.53 & $7.5-15.5$ & 2.66 & 3.74 & 2.31 & 4.04 & 0.72 & $3,738.33$ & 61.65 \\
\hline Uganda & LI-SSA & 1993-2005 & 316 & 13.35 & $8.5-15.5$ & 2.27 & 3.94 & 1.65 & 6.92 & 0.66 & 244.37 & 4.91 \\
\hline UK & $\mathrm{HI}$ & $1988-2005$ & 1543 & 20.50 & $20-21$ & 4.88 & 5.65 & 4.00 & 2.54 & 0.69 & $22,926.57$ & 3.60 \\
\hline Ukraine & LMI-T & 1993-2005 & 427 & 11.98 & $6.75-14.5$ & 1.86 & 4.00 & 1.00 & -1.54 & 0.67 & 737.49 & 477.01 \\
\hline Uruguay & UMI-LA & 1992.2005 & 460 & 15.14 & $14-15$ & 3.00 & 2.85 & 1.72 & 2.39 & 0.59 & $6,620.89$ & 23.61 \\
\hline USA & $\mathrm{HI}$ & $1988-2005$ & 16,752 & 19.78 & $18-21$ & 4.60 & 5.81 & 4.00 & 3.01 & 0.22 & $31,632.31$ & 3.06 \\
\hline Venezuela & UMI-LA & $1988-2005$ & 715 & 14.29 & $4.5-17.25$ & 2.67 & 3.56 & 1.53 & 2.28 & 0.57 & $4,909.13$ & 39.35 \\
\hline Vietnam & LI-T & $1992-2005$ & 85 & 5.93 & $1.75-9.5$ & 2.22 & 4.36 & 1.81 & 7.68 & 0.86 & 379.34 & 4.12 \\
\hline Zimbabwe & LI-SSA & 1993-2005 & 188 & 12.38 & $9.5-11.75$ & 1.77 & 2.85 & 2.32 & -0.90 & 0.76 & 585.45 & 114.75 \\
\hline Total mean & & & 84768 & 14.86 & & 3.46 & 4.16 & 2.60 & 3.58 & 0.67 & $8,900.87$ & 36.19 \\
\hline
\end{tabular}

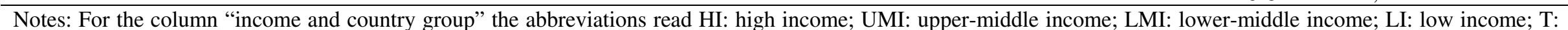

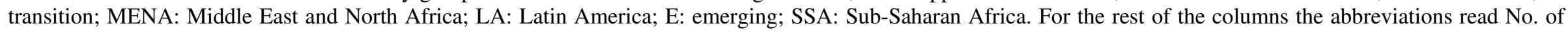
observ.: Number of observations; Bureauc. quality: Bureaucratic quality; Concent.: 3-bank concentration ratio. GDP per capita is in million \$US. 
Table B2

Averages for the bank-level variables by country

\begin{tabular}{|c|c|c|c|c|c|c|c|c|}
\hline Country & $\mathrm{c}$ & $\mathrm{q}$ & $\mathrm{d}$ & $\mathrm{p}$ & w1 & w2 & Capital. & $\begin{array}{c}\text { Bank } \\
\text { size }\end{array}$ \\
\hline Albania & 17,673 & 184,819 & 281,161 & 0.25 & 0.01 & 1.18 & 0.15 & 11.85 \\
\hline Algeria & 91,755 & $1,569,639$ & $1,941,107$ & 0.15 & 0.01 & 1.46 & 0.15 & 13.37 \\
\hline Argentina & 125,303 & 667,329 & 604,121 & 0.30 & 0.05 & 3.38 & 0.25 & 12.19 \\
\hline Australia & $2,352,223$ & $32,610,134$ & $21,056,247$ & 0.13 & 0.01 & 3.69 & 0.12 & 15.55 \\
\hline Austria & 212,934 & $3,189,420$ & $2,811,961$ & 0.18 & 0.02 & 3.90 & 0.10 & 12.84 \\
\hline Azerbaijan & 57,261 & 405,147 & 543,160 & 0.43 & 0.02 & 1.35 & 0.22 & 10.79 \\
\hline Bangladesh & 53,098 & 558,625 & 528,866 & 0.13 & 0.01 & 2.85 & 0.07 & 12.86 \\
\hline Belarus & 73,674 & 435,833 & 468,801 & 0.39 & 0.03 & 1.27 & 0.23 & 11.92 \\
\hline Belgium & $2,092,800$ & $2,4207,213$ & $21,906,234$ & 0.19 & 0.01 & 3.09 & 0.16 & 14.12 \\
\hline Bolivia & 31,400 & 277,432 & 266,010 & 0.12 & 0.02 & 2.72 & 0.20 & 12.07 \\
\hline Brazil & 763,752 & $3,581,466$ & $2,102,176$ & 0.51 & 0.02 & 1.89 & 0.21 & 13.35 \\
\hline Bulgaria & 37,569 & 442,989 & 521,364 & 0.25 & 0.01 & 1.28 & 0.16 & 12.46 \\
\hline Burkina-Faso & 12,775 & 109,303 & 124,534 & 0.14 & 0.02 & 1.36 & 0.09 & 11.71 \\
\hline Cameroon & 16,722 & 174,027 & 233,059 & 0.15 & 0.02 & 1.19 & 0.08 & 12.18 \\
\hline Canada & $1,279,017$ & $15,606,783$ & $17,012,452$ & 0.27 & 0.02 & 2.97 & 0.15 & 14.09 \\
\hline Chile & 258,732 & $2,157,396$ & $1,884,710$ & 0.30 & 0.02 & 1.98 & 0.20 & 13.49 \\
\hline China & $1,166,485$ & $30,514,633$ & $30,735,216$ & 0.06 & 0.01 & 1.92 & 0.08 & 15.10 \\
\hline Colombia & 266,831 & $1,727,364$ & $1,672,315$ & 0.24 & 0.03 & 2.07 & 0.12 & 13.82 \\
\hline Costa Rica & 38,953 & 249,279 & 245,030 & 0.41 & 0.04 & 2.24 & 0.20 & 11.15 \\
\hline Czech Rep & 209,038 & $3,070,848$ & $3,760,435$ & 0.14 & 0.01 & 2.56 & 0.11 & 14.36 \\
\hline Denmark & 245,828 & $4,325,073$ & $2,683,428$ & 0.11 & 0.02 & 4.21 & 0.14 & 12.93 \\
\hline Dominican Rep & 44,379 & 224,356 & 225,250 & 0.29 & 0.04 & 2.96 & 0.17 & 10.71 \\
\hline Ecuador & 28,638 & 183,949 & 213,495 & 0.26 & 0.02 & 2.79 & 0.07 & 10.83 \\
\hline Egypt & 256,735 & $2,223,615$ & $2,862,343$ & 0.14 & 0.01 & 2.45 & 0.10 & 14.15 \\
\hline El Salvador & 55,008 & 637,057 & 534,025 & 0.12 & 0.02 & 3.19 & 0.18 & 12.72 \\
\hline Estonia & 139,164 & $2,377,942$ & $2,404,605$ & 0.18 & 0.02 & 1.88 & 0.15 & 13.04 \\
\hline Finland & $1,036,163$ & $18,023,568$ & $14,447,288$ & 0.14 & 0.03 & 3.92 & 0.17 & 15.34 \\
\hline France & $1,332,399$ & $16,462,742$ & $14,459,377$ & 0.15 & 0.02 & 4.45 & 0.12 & 14.63 \\
\hline Germany & 149,962 & $2,217,411$ & $2,079,878$ & 0.12 & 0.02 & 2.83 & 0.07 & 13.13 \\
\hline Ghana & 20,315 & 118,517 & 131,083 & 0.36 & 0.03 & 1.63 & 0.14 & 11.21 \\
\hline Greece & 868,380 & $11,855,782$ & $11,234,186$ & 0.19 & 0.01 & 1.47 & 0.11 & 15.26 \\
\hline Guatemala & 35,108 & 352,008 & 375,916 & 0.17 & 0.02 & 1.64 & 0.12 & 12.07 \\
\hline Hong Kong & 561,661 & $12,431,545$ & $14,786,527$ & 0.18 & 0.01 & 5.89 & 0.20 & 14.63 \\
\hline Hungary & 263,962 & $2,196,173$ & $2,219,706$ & 0.32 & 0.02 & 2.72 & 0.14 & 13.55 \\
\hline India & 597,598 & $7,298,022$ & $6,540,605$ & 0.11 & 0.01 & 1.64 & 0.09 & 14.82 \\
\hline Indonesia & 193,295 & $1,462,844$ & $1,631,781$ & 0.19 & 0.01 & 1.78 & 0.14 & 13.27 \\
\hline Ireland & $1,034,095$ & $20,100,467$ & $15,096,238$ & 0.17 & 0.01 & 4.61 & 0.11 & 15.82 \\
\hline Israel & $1,025,055$ & $13,105,566$ & $12,831,748$ & 0.11 & 0.01 & 2.32 & 0.07 & 15.61 \\
\hline Italy & 276,002 & $4,357,174$ & $3,329,934$ & 0.12 & 0.02 & 4.59 & 0.13 & 13.09 \\
\hline Jamaica & 108,064 & 865,808 & 592,906 & 0.23 & 0.03 & 2.93 & 0.16 & 13.23 \\
\hline Japan & 427,160 & $18,905,061$ & $15,961,430$ & 0.04 & 0.01 & 1.77 & 0.06 & 14.50 \\
\hline Jordan & 239,519 & $3,173,771$ & $4,280,164$ & 0.12 & 0.01 & 1.23 & 0.11 & 14.36 \\
\hline Kazakhstan & 200,177 & $1,164,502$ & 997,100 & 0.18 & 0.02 & 1.55 & 0.22 & 12.77 \\
\hline Kenya & 24,945 & 169,774 & 200,326 & 0.20 & 0.03 & 2.04 & 0.18 & 11.55 \\
\hline Korea & $2,378,464$ & $37,621,755$ & $25,710,409$ & 0.09 & 0.01 & 2.36 & 0.06 & 16.44 \\
\hline Latvia & 47,684 & 640,678 & 664,384 & 0.28 & 0.01 & 2.04 & 0.11 & 12.75 \\
\hline
\end{tabular}




\begin{tabular}{|c|c|c|c|c|c|c|c|c|}
\hline Lithuania & 71,997 & $1,210,696$ & $1,322,538$ & 0.31 & 0.02 & 1.22 & 0.10 & 13.40 \\
\hline Madagascar & 9,098 & 81,237 & 141,967 & 0.18 & 0.01 & 1.89 & 0.10 & 11.79 \\
\hline Malaysia & 536,073 & $5,389,672$ & $6,129,749$ & 0.12 & 0.01 & 4.79 & 0.15 & 14.75 \\
\hline Mexico & 887,872 & $4,839,824$ & $5,010,343$ & 0.36 & 0.04 & 1.58 & 0.21 & 13.99 \\
\hline Morocco & 302,007 & $5,594,582$ & $6,199,662$ & 0.08 & 0.01 & 0.66 & 0.08 & 15.35 \\
\hline Mozambique & 23,501 & 101,851 & 181,006 & 0.36 & 0.04 & 1.49 & 0.14 & 11.34 \\
\hline Netherlands & $3,027,490$ & $50,503,881$ & $42,617,785$ & 1.78 & 0.02 & 4.26 & 0.14 & 15.45 \\
\hline New Zealand & $1,060,277$ & $13,645,488$ & $10,332,742$ & 9.44 & 0.01 & 4.58 & 0.05 & 15.95 \\
\hline Nicaragua & 28,562 & 207,066 & 209,407 & 0.05 & 0.02 & 1.86 & 0.06 & 11.76 \\
\hline Nigeria & 99,089 & 458,024 & 750,970 & 0.80 & 0.03 & 1.43 & 0.15 & 12.69 \\
\hline Norway & 156,882 & $2,863,654$ & $1,942,913$ & 0.07 & 0.01 & 3.33 & 0.10 & 12.91 \\
\hline Pakistan & 118,066 & $1,463,279$ & $1,521,860$ & 0.10 & 0.01 & 1.69 & 0.11 & 13.69 \\
\hline Paraguay & 74,454 & 99,499 & 108,160 & 0.36 & 0.03 & 1.73 & 0.13 & 11.63 \\
\hline Peru & 245,215 & $2,179,336$ & $2,358,920$ & 0.27 & 0.02 & 1.77 & 0.13 & 13.50 \\
\hline Philippines & 110,924 & $1,240,971$ & $1,327,389$ & 0.14 & 0.02 & 3.01 & 0.17 & 13.02 \\
\hline Poland & 224,325 & $2,569,029$ & $2,791,207$ & 0.19 & 0.02 & 3.09 & 0.13 & 13.94 \\
\hline Portugal & 740,777 & $10,503,901$ & $7,671,289$ & 0.21 & 0.01 & 2.86 & 0.12 & 14.85 \\
\hline Romania & 137,809 & 919,993 & $1,230,846$ & 0.31 & 0.03 & 1.84 & 0.15 & 13.07 \\
\hline Russia & 50,474 & 369,620 & 350,661 & 0.79 & 0.04 & 2.46 & 0.22 & 10.76 \\
\hline Senegal & 16,598 & 182,820 & 198,940 & 0.12 & 0.02 & 1.32 & 0.10 & 11.90 \\
\hline Singapore & 703,414 & $14,981,655$ & $18,834,257$ & 0.27 & 0.02 & 9.04 & 0.29 & 14.56 \\
\hline South Africa & $1,231,529$ & $10,304,488$ & $11,256,277$ & 0.45 & 0.03 & 4.83 & 0.22 & 14.11 \\
\hline Spain & 834,332 & $15,421,583$ & $9,731,326$ & 2.28 & 0.01 & 3.16 & 0.13 & 14.35 \\
\hline Sri Lanka & 90,064 & 568,928 & 654,389 & 0.18 & 0.02 & 1.26 & 0.08 & 12.83 \\
\hline Sweden & 247,862 & $5,179,678$ & $3,387,436$ & 0.09 & 0.02 & 4.64 & 0.14 & 11.89 \\
\hline Switzerland & 361,010 & $2,877,707$ & $4,339,340$ & 0.20 & 0.02 & 2.98 & 0.11 & 12.45 \\
\hline Tanzania & 10,893 & 72,393 & 108,081 & 0.25 & 0.02 & 1.61 & 0.13 & 11.12 \\
\hline Thailand & 405,521 & $7,252,971$ & $7,299,515$ & 0.07 & 0.01 & 1.46 & 0.13 & 15.08 \\
\hline Tunisia & 83,153 & 908,724 & 851,027 & 0.20 & 0.02 & 1.73 & 0.12 & 13.41 \\
\hline Turkey & 939,710 & $6,088,329$ & $5,714,579$ & 0.39 & 0.02 & 2.70 & 0.22 & 14.31 \\
\hline Uganda & 10,306 & 67,494 & 64,046 & 0.28 & 0.03 & 2.03 & 0.15 & 11.10 \\
\hline UK & $2,206,587$ & $35,814,569$ & $32,412,140$ & 0.09 & 0.02 & 7.42 & 0.17 & 14.24 \\
\hline Ukraine & 78,351 & 516,438 & 539,415 & 0.29 & 0.02 & 1.35 & 0.15 & 12.47 \\
\hline Uruguay & 295,691 & 252,402 & 360,737 & 0.26 & 0.04 & 2.54 & 0.21 & 11.60 \\
\hline USA & $1,018,557$ & $13,800,000$ & $8,664,069$ & 0.12 & 0.02 & 6.84 & 0.11 & 14.40 \\
\hline Venezuela & 143,799 & 980,751 & $1,126,651$ & 0.46 & 0.03 & 2.53 & 0.23 & 12.83 \\
\hline Vietnam & 479,339 & $7,626,395$ & $6,218,222$ & 0.42 & 0.02 & 1.23 & 0.08 & 13.34 \\
\hline Zimbabwe & 109,872 & 362,954 & 276,886 & 0.87 & 0.03 & 0.35 & 0.17 & 12.14 \\
\hline Total mean & 451,419 & $6,330,199$ & $5,588,450$ & 0.39 & 0.02 & 2.62 & 0.14 & 13.26 \\
\hline
\end{tabular}

Notes: The table presents descriptive statistics of the bank-level variables used in the empirical analysis. The variables are defined as follows. c: real total expenses (proxy of bank cost); q: real total earning assets (proxy of bank output); d: real total deposits and short-term funding; p: total revenue/total earning assets (proxy of the price of bank output); $\mathrm{w}_{1}$ : personnel expenses/total assets (price of labor); $\mathrm{w}_{2}$ : total depreciation and other capital expenses/total fixed assets (proxy for the price of physical capital; capital: equity capital/total assets (proxy for bank capitalization); bank size: natural logarithm of real total assets (proxy for bank size). c, q and $\mathrm{d}$ are in thousand \$US. 


\section{References}

Abiad, A., Detragiache, E., Tressel., T., 2010. A new database of financial reforms. IMF Staff Papers 57, 281-302.

Altunbas, Y., Gardener, E.P.M., Molyneux, P., Moore, B., 2001. Efficiency in European banking. European Economic Review 45, 1931-1955.

Andrianova, S., Demetriades, P., Shortland, A., 2008. Government ownership of banks, institutions, and financial development. Journal of Development Economics 85, 218-252.

Beck, T., Demirgüç-Kunt, A., 2009. Financial institutions and markets across countries and over time: Data and analysis. World Bank Policy Research Working Paper No. 4943.

Beck, T., Hesse, H., 2009. Why are interest spreads so high in Uganda? Journal of Development Economics 88, 192-204.

Berger, A.N., Bonime, S.D., Covitz, D.M., Hancock, D., 2000. Why are bank profits so persistent? The roles of product market competition, informational opacity, and regional/macroeconomic shocks. Journal of Banking and Finance 24, 1203-1235.

Berger, A.N., Humphrey, D.B., 1997. Efficiency of financial institutions: International survey and directions for future research. European Journal of Operational Research 98, 175-212.

Berger, A., Klapper, L., Turk-Ariss, R., 2009. Bank competition and financial stability. Journal of Financial Services Research 35, 99-118.

Bikker, J., Haaf, K., 2002. Competition, concentration and their relationship: An empirical analysis of the banking industry. Journal of Banking and Finance 26, 2191-2214.

Bikker, J.A., Spierdijk, L., 2008. How banking competition changed over time. Tjalling C. Koopmans Research Institute Discussion Paper Series No. 08-04. 
Binder, M., Hsiao, C., Pesaran, M.H., 2003. Estimation and inference in short panel vector autoregressions with unit roots and cointegration. Cambridge Working Papers in Economics, No. 0003.

Blundell, R., Bond, S., 1998. Initial conditions and moment restrictions in dynamic panel data models, Journal of Econometrics 87, 115-143.

Bond, S., 2002. Dynamic panel data models: A guide to microdata methods and practice. CeMMAP working papers CWP09/02, Centre for Microdata Methods and Practice, Institute for Fiscal Studies.

Bonin, J., Hasan, I., and Wachtel, P., 2005. Bank performance, efficiency and ownership in transition countries. Journal of Banking and Finance 29, 31-53.

Boone, J., 2008. A new way to mesure compeition. Economic Journal 188, 1245-1261.

Boone, J., Griffith, R., Harrison, R., 2005. Measuring competion. Advanced Institute of Management Research Paper No. 022.

Boubakri, N., Cosset, J.C., Guedhami, O., 2008. Privatization in developing countries: Performance and ownership effects. Development Policy Review 26, 275-308.

Brissimis, S.N., Delis, M.D., Papanikolaou, N.I., 2008. Exploring the nexus between banking sector reform and performance: Evidence from Central and Eastern European countries. Journal of Banking and Finance, forthcoming.

Brock, P.L., Suarez, L.R., 2000. Understanding the behavior of bank spreads in Latin America. Journal of Development Economics 63, 113-134.

Carbó, S., Humphrey, D., Maudos, J., Molyneux, P., 2009. Cross-country comparisons of competition and pricing power in European banking. Journal of International Money and Finance 28, 115-134. 
Cetorelli, N., Strahan, P.E., 2006. Finance as a barrier to entry: Bank competition and industry structure in local U.S. markets. Journal of Finance 61, 437-461.

Claessens, S., 2010. Compeition in the financial sector: Overview of competition policies. World Bank Research Observer 24, 83-118.

Claessens, S., Laeven, L., 2004. What drives bank competition? Some international evidence. Journal of Money, Credit, and Banking 36, 563-83.

Cleveland, W.S, Devlin, S.J., 1988. Locally weighted regression and smoothing scatterplots. Journal of the American Statistical Association 83, 596-610.

Delis, M.D., 2010. Competitive conditions in the Central and Eastern European banking systems. OMEGA 38, 268-274.

Delis, M.D., Hasan, I. Kazakis, P., 2010. Bank regulations and income inequality: Empirical evidence. MPRA Paper 27379, University Library of Munich, Germany.

Delis, M.D., Tsionas, E.G., 2009. The joint estimation of bank-level market power and efficiency. Journal of Banking and Finance 33, 1842-1850.

Demetriades, P., Andrianova, S., 2004. Finance and growth: What we know and what we need to know. In C.A.E. Goodhart (ed.), Financial Development and Growth: Explaining the Links, Palgrave Macmillan, pp. 38-65.

Demirguc-Kunt, A., Detragiache, E., 1998. The determinants of banking crises in developing and developed countries. IMF Staff Papers 45, 81-109.

Demirguc-Kunt A., Laeven L., Levine R., 2004. Regulations, market structure, institutions, and the cost of financial intermediation. Journal of Money, Credit, and Banking 36, 593-622.

Estache, A., Wren-Lewis, L., 2009. Toward a theory of regulation for developing countries: Following Jean-Jacques Laffont's lead. Journal of Economic Literature 47, 729-770. 
Eyal G., Szelenyi I., and Townsley E., 1998. Making Capitalism without Capitalists. New York: Verso.

Galindo, A., Schiantarelli, F., Weiss, A., 2007. Does financial liberalization improve the allocation of investment? Micro-evidence from developing countries. Journal of Development Economics 83, 562-587.

Hasan, I., Marton, K., 2003. Development and efficiency of the banking sector in a transitional economy: Hungarian experience. Journal of Banking and Finance 24, 2249-2271.

Jayaratne, J., Strahan, P.E., 1998. Entry restrictions, industry evolution, and dynamic efficiency: Evidence from commercial banking. Journal of Law and Economics 41, 239-73.

Joskow, P. Scmalensee, R., Tsukanova, N., 1994. Competition policy in Russia during and after privatization. Brookings Papers on Economic Activity: Microeconomics, 301-381.

Kaminsky, G.L., Schmukler, S.L., 2003. Short-run pain, long-run gain: The effects of financial liberalization. IMF Working Paper No. 03/34.

King, R.G., Levine, R., 1993. Finance and growth: Schumpeter might be right. Quarterly Journal of Economics 108, 717-737.

Koetter, M., Poghosyan, T., 2009. The identification of technology regimes in banking: Implications for the market power-fragility nexus. Journal of Banking and Finance 33, 14131422.

Kumbhakar, S.C., Park, B.U., Simar, L., Tsionas, E.G., 2007. Nonparametric stochastic frontiers: a local maximum likelihood approach. Journal of Econometrics 137, 1-27.

Leuvensteijn, M., Sørensen, C.K., Bikker, J.A., Rixtel, A.A.R.J.M, 2008. Impact of bank competition on the interest rate pass-through in the euro area. European Central Bank Working Paper Series No. 885. 
Loader, C., 1999. Local Regression and Likelihood. New York: Springer.

Nerlove, M., 2002. Properties of alternative estimators of dynamic panel data models: an empirical analysis of cross-country data for the study of economic growth. In: Essays in panel data econometrics. Cambridge University Press, 136-169.

Panzar, J. \& Rosse, J., 1987. Testing for "monopoly" equilibrium. Journal of Industrial Economics $35,443-456$.

Schaeck, K., Cihak, M., 2010. Competition, efficiency, and soundness in banking: An industrial organization perspective. Discussion Paper 2010-68S, Tilburg University, Center for Economic Research.

Staniszkis, J., 1991. The Dynamics of Breakthrough. Berkeley: University of California Press.

Tirole, J., 1991. Privatization in eastern Europe: Incentives and the economics of transition. In: Blanchard, O., Fischer, S. (Eds.), The NBER Macroeconomics Annual 1991. MIT press, Cambridge, Massachusetts.

Vives, X, 2008. Innovation and competitive pressure. Journal of Industrial Economics 56, 419-469.

Yeyati, E.L., Micco, A., 2007. Concentration and foreign penetration in Latin American banking sectors: Impact on competition and risk. Journal of Banking and Finance 31, 1633-1647. 
Table 1

Estimates of bank market power using the Boone method (country and year averages)

\begin{tabular}{|c|c|c|c|c|c|c|c|c|c|c|c|c|c|c|c|c|c|c|c|c|}
\hline & 1987 & 1988 & 1989 & 1990 & 1991 & 1992 & 1993 & 1994 & 1995 & 1996 & 1997 & 1998 & 1999 & 2000 & 2001 & 2002 & 2003 & 2004 & 2005 & Mean \\
\hline Albania & & & & & & -4.83 & -4.78 & -5.42 & -4.73 & -4.38 & -2.76 & -2.55 & -2.67 & -3.73 & -4.92 & -4.92 & -5.47 & -5.18 & -4.76 & -4.36 \\
\hline Algeria & & & & & & & & -5.21 & -4.03 & -4.77 & -4.77 & -4.98 & -5.35 & -4.96 & -4.64 & -4.82 & -4.15 & -4.72 & -3.65 & -4.67 \\
\hline Argentina & & & 0.30 & -3.20 & -2.81 & -4.01 & -4.60 & -5.95 & -7.38 & -7.19 & -6.71 & -6.51 & -6.13 & -5.83 & -5.51 & -8.79 & -7.58 & -6.61 & -3.32 & -5.40 \\
\hline Australia & & & & & & -3.08 & -3.67 & -3.91 & -3.78 & -3.49 & -3.95 & -3.80 & -3.75 & -3.68 & -3.80 & -3.35 & -3.12 & -3.02 & -2.51 & -3.49 \\
\hline Austria & & -2.38 & -2.29 & -2.45 & -2.51 & -2.10 & -2.98 & -3.00 & -2.96 & -2.99 & -3.19 & -2.75 & -2.36 & -2.91 & -3.13 & -3.40 & -2.74 & -3.17 & -2.68 & -2.78 \\
\hline Azerbaijan & & & & & & 4.70 & 3.15 & 2.66 & 3.61 & 5.58 & 1.24 & 1.58 & -0.40 & -1.94 & -2.01 & -0.56 & -0.88 & 0.18 & -0.68 & 1.16 \\
\hline Bangladesh & & & & & & -4.22 & -4.66 & -4.81 & -4.63 & -4.27 & -4.46 & -4.50 & -4.81 & -4.54 & -4.39 & -4.61 & -4.71 & -4.89 & -4.80 & -4.59 \\
\hline Belarus & & & & & & 0.94 & 0.07 & 0.66 & 0.77 & -0.66 & 0.94 & -0.95 & 0.89 & 0.52 & -0.86 & 0.44 & -1.47 & -2.04 & -2.15 & -0.21 \\
\hline Belgium & & -4.28 & -4.35 & -4.73 & -5.09 & -5.39 & -5.60 & -5.67 & -5.70 & -5.58 & -5.66 & -5.54 & -5.12 & -5.21 & -4.89 & -4.47 & -3.83 & -3.72 & -3.68 & -4.92 \\
\hline Bolivia & & & & & & & -7.19 & -4.13 & -3.58 & -3.85 & -3.85 & -3.74 & -3.50 & -4.12 & -4.16 & -4.11 & -3.86 & -4.03 & -3.85 & -4.15 \\
\hline Brazil & & & & & -4.92 & -4.15 & -4.40 & -3.00 & -3.32 & -3.22 & -3.72 & -3.70 & -3.19 & -3.43 & -3.35 & -3.35 & -3.32 & -3.52 & -3.63 & -3.61 \\
\hline Bulgaria & & & & & -2.26 & -4.27 & -3.33 & -3.46 & -1.86 & 1.36 & 0.50 & -1.05 & -2.41 & -2.08 & -3.33 & -4.10 & -4.02 & -3.55 & -3.58 & -2.50 \\
\hline Burkina-Faso & & & & & & & & & & -0.58 & -2.38 & -2.04 & -2.69 & -2.83 & -2.28 & -1.45 & -1.79 & -3.32 & -3.28 & -2.26 \\
\hline Cameroon & & & & & & & & -8.36 & -8.04 & -8.61 & -3.63 & -2.55 & -2.40 & -4.55 & -2.80 & -3.08 & -3.16 & -3.11 & -3.77 & -4.51 \\
\hline Canada & & -3.01 & -2.86 & -3.40 & -3.76 & -3.23 & -3.07 & -3.83 & -4.71 & -4.60 & -4.71 & -4.79 & -4.75 & -4.82 & -3.75 & -4.40 & -4.07 & -3.42 & -4.63 & -3.99 \\
\hline Chile & & -2.25 & -1.14 & -0.19 & -2.44 & -3.12 & -3.41 & -3.67 & -3.50 & -3.67 & -3.75 & -3.46 & -3.08 & -3.74 & -3.22 & -2.74 & -3.65 & -3.31 & -3.45 & -2.99 \\
\hline China & & -7.77 & -6.58 & -6.52 & -6.40 & -6.02 & -6.93 & -6.89 & -6.81 & -6.89 & -6.95 & -6.16 & -6.55 & -6.91 & -6.90 & -6.26 & -6.39 & -6.31 & -7.05 & -6.68 \\
\hline Colombia & & & -0.73 & 0.26 & 0.61 & -1.47 & -1.08 & -1.55 & -2.28 & -2.39 & -2.92 & -4.28 & -6.63 & -5.31 & -4.21 & -3.77 & -3.23 & -3.07 & -2.81 & -2.64 \\
\hline Costa Rica & & & & & -1.59 & -1.09 & -1.02 & -0.60 & -0.62 & -0.44 & -1.49 & -3.11 & -3.05 & -2.34 & -2.29 & -2.13 & -1.80 & -1.85 & -1.71 & -1.68 \\
\hline Czech Rep & & & & & -1.65 & -2.73 & -3.61 & -3.29 & -3.52 & -5.59 & -4.72 & -4.82 & -4.62 & -4.57 & -4.23 & -4.27 & -4.23 & -4.67 & -3.93 & -4.03 \\
\hline Denmark & & -2.19 & -1.86 & -1.98 & -2.27 & -4.90 & -1.76 & -2.32 & -2.06 & -2.23 & -2.43 & -2.80 & -2.80 & -2.95 & -2.76 & -2.73 & -2.32 & -2.37 & -1.73 & -2.45 \\
\hline Dominican Rep & & & & & & -2.46 & -1.66 & 0.69 & -0.58 & -1.57 & -2.25 & -1.57 & -1.69 & -2.24 & -2.85 & -0.01 & 1.14 & 3.02 & 0.80 & -0.80 \\
\hline Ecuador & & & & & & & & & & & -3.08 & -2.24 & -4.58 & -5.97 & -5.90 & -5.10 & -5.34 & -4.98 & -4.12 & -4.59 \\
\hline Egypt & & -3.16 & -2.84 & -3.02 & -3.24 & -4.29 & -4.37 & -4.13 & -4.11 & -4.21 & -4.21 & -4.08 & -4.01 & -4.31 & -4.44 & -4.68 & -4.64 & -4.68 & -4.91 & -4.07 \\
\hline El Salvador & & & & & & & & & -1.61 & -1.71 & -2.34 & -1.82 & -3.03 & -2.45 & -1.81 & -1.54 & -2.01 & -2.44 & -2.08 & -2.08 \\
\hline Estonia & & & & & & & 1.99 & -0.31 & -0.20 & -1.30 & -2.63 & -3.88 & -1.70 & -2.00 & -1.71 & -2.10 & -2.21 & -2.25 & -2.25 & -1.58 \\
\hline Finland & & -2.86 & -2.94 & -2.94 & -2.38 & -2.13 & -2.81 & -2.93 & -2.51 & -1.75 & -1.63 & -1.43 & -1.25 & -1.87 & -1.20 & -1.98 & -2.04 & -2.15 & -2.39 & -2.18 \\
\hline France & -3.19 & -2.82 & -2.99 & -3.11 & -3.55 & -4.33 & -4.77 & -4.93 & -4.82 & -5.03 & -5.03 & -4.57 & -4.42 & -4.22 & -4.41 & -4.55 & -4.72 & -4.25 & -4.20 & -4.21 \\
\hline Germany & & & & & -4.00 & -4.55 & -4.47 & -4.56 & -4.63 & -4.60 & -4.33 & -3.89 & -4.10 & -3.46 & -4.29 & -4.05 & -4.02 & -4.23 & -3.83 & -4.20 \\
\hline Ghana & & & & & & & & & -2.16 & -0.58 & -3.03 & -3.81 & -1.80 & -0.99 & -0.72 & -0.25 & 0.91 & 0.56 & -0.49 & -1.12 \\
\hline Greece & & -1.36 & -1.96 & -1.51 & -2.39 & -2.61 & -1.15 & -1.89 & -1.80 & -1.12 & -1.07 & -1.72 & -1.48 & -1.44 & -1.52 & -1.39 & -1.39 & -1.56 & -1.80 & -1.62 \\
\hline
\end{tabular}




\begin{tabular}{|c|c|c|c|c|c|c|c|c|c|c|c|c|c|c|c|c|c|c|c|c|}
\hline Guatemala & & & & & & -3.29 & -3.31 & -3.60 & -3.89 & -3.38 & -3.23 & -2.80 & -2.75 & -3.16 & -3.55 & -3.60 & -6.57 & -4.77 & -1.81 & -3.55 \\
\hline Hong Kong & & & & & & -0.65 & -0.13 & -0.25 & -0.39 & -0.84 & -0.42 & -0.21 & -0.37 & -0.41 & -1.82 & -1.30 & -0.95 & -1.37 & -2.04 & -0.80 \\
\hline Hungary & & & & -1.55 & -1.61 & -1.20 & -1.44 & -2.80 & -2.02 & -3.05 & -3.71 & -3.78 & -4.59 & -3.34 & -2.69 & -2.73 & -2.66 & -2.52 & -2.51 & -2.64 \\
\hline India & & & & & & -5.21 & -5.24 & -4.73 & -4.68 & -4.70 & -4.79 & -5.06 & -4.99 & -5.10 & -5.08 & -5.01 & -4.61 & -4.97 & -4.74 & -4.92 \\
\hline Indonesia & & & & -0.91 & -0.88 & -0.74 & -0.33 & -0.70 & -0.90 & -0.17 & -1.01 & -0.98 & -0.98 & -0.34 & -0.38 & -0.19 & -0.91 & -0.03 & 0.35 & -0.57 \\
\hline Ireland & & & & & & -3.62 & -2.90 & -4.26 & -4.07 & -4.38 & -4.65 & -4.51 & -4.58 & -4.64 & -4.57 & -5.58 & -5.53 & -4.59 & -5.11 & -4.50 \\
\hline Israel & & & & -2.52 & -2.78 & -3.50 & -3.24 & -3.35 & -3.74 & -3.62 & -3.43 & -3.65 & -3.84 & -4.56 & -3.75 & -4.15 & -3.84 & -3.77 & -3.67 & -3.59 \\
\hline Italy & -2.38 & -3.14 & -3.08 & -3.16 & -3.20 & -3.33 & -3.53 & -4.04 & -4.09 & -4.29 & -4.35 & -4.24 & -3.85 & -3.02 & -4.65 & -5.37 & -4.75 & -5.14 & -5.49 & -3.85 \\
\hline Jamaica & & & & & & & & & & & & & & & & -1.76 & -0.67 & -1.17 & -0.81 & -1.10 \\
\hline Japan & & -5.11 & -5.36 & -5.66 & -5.67 & -5.94 & -5.99 & -5.96 & -6.09 & -5.88 & -6.14 & -6.19 & -6.07 & -6.04 & -6.04 & -5.87 & -5.74 & -5.72 & -5.58 & -5.84 \\
\hline Jordan & & & & & & -3.12 & -3.47 & -2.82 & -2.57 & -2.65 & -2.88 & -2.88 & -3.04 & -2.95 & -2.81 & -3.11 & -2.68 & -2.45 & -2.10 & -2.82 \\
\hline Kazakhstan & & & & & & & & & & -0.49 & 1.52 & 0.36 & -0.72 & -1.65 & -1.42 & -1.80 & -1.52 & -2.48 & -2.20 & -1.04 \\
\hline Kenya & & & & & & -4.07 & -4.26 & -4.27 & -2.04 & -2.55 & -2.53 & -1.96 & -2.29 & -2.55 & -2.00 & -1.96 & -2.49 & -1.81 & -2.57 & -2.67 \\
\hline Korea & & & & & -5.18 & -4.94 & -5.28 & -5.57 & -5.74 & -5.77 & -6.56 & -7.31 & -6.23 & -5.90 & -5.08 & -5.01 & -4.62 & -4.32 & -4.52 & -5.44 \\
\hline Latvia & & & & & & 0.58 & 0.83 & -0.66 & -1.79 & -2.45 & -1.34 & -2.18 & -2.00 & -1.74 & -2.89 & -2.12 & -2.18 & -2.31 & -3.52 & -1.70 \\
\hline Lithuania & & & & & & 0.61 & 6.83 & -2.25 & -4.26 & -2.53 & -3.72 & -2.04 & -1.87 & -2.73 & -3.54 & -3.39 & -3.39 & -3.56 & -3.64 & -2.11 \\
\hline Madagascar & & & & & & & & 0.61 & 1.47 & -0.68 & -1.72 & -1.39 & -0.45 & -0.18 & -0.52 & -0.81 & -0.13 & -0.24 & 0.15 & -0.32 \\
\hline Malaysia & & & & & & & -4.93 & -4.90 & -4.47 & -4.45 & -4.53 & -4.99 & -4.63 & -4.19 & -4.60 & -4.90 & -4.88 & -4.82 & -4.58 & -4.68 \\
\hline Mexico & & & -0.09 & -0.79 & -1.64 & -1.47 & -2.21 & -2.92 & -1.64 & -2.82 & -3.95 & -3.44 & -2.94 & -3.07 & -1.84 & -2.97 & -1.97 & -2.48 & -0.69 & -2.17 \\
\hline Morocco & & & & & & -4.28 & -1.99 & -2.28 & -2.27 & -2.04 & -2.60 & -3.10 & -3.85 & -3.71 & -3.46 & -3.46 & -3.43 & -3.42 & -4.08 & -3.14 \\
\hline Mozambique & & & & & & & & & & 0.08 & -1.70 & 0.63 & -4.59 & -5.79 & 1.02 & -2.19 & -0.35 & -0.01 & -1.38 & -1.43 \\
\hline Netherlands & & -4.25 & -4.87 & -4.77 & -4.81 & -5.25 & -3.58 & -3.97 & -4.07 & -3.99 & -3.76 & -3.52 & -2.61 & -2.68 & -3.34 & -5.22 & -4.18 & -4.02 & -3.80 & -4.01 \\
\hline New Zealand & & & & & & & & & & -0.04 & -0.72 & -0.92 & -1.04 & -0.96 & -1.08 & -0.92 & -1.03 & -0.28 & -0.36 & -0.74 \\
\hline Nicaragua & & & & & & -1.08 & -0.86 & -2.20 & -4.00 & -3.50 & -4.35 & -4.01 & -3.32 & -2.75 & -1.15 & -1.65 & -1.95 & -0.59 & -0.87 & -2.31 \\
\hline Nigeria & & & & & & -0.78 & 0.09 & -1.29 & -1.81 & -2.37 & 0.07 & -0.59 & -2.01 & -1.33 & -0.81 & -1.24 & -1.62 & -1.96 & -2.63 & -1.31 \\
\hline Norway & & & -2.68 & -3.06 & -3.35 & -2.82 & -2.33 & -2.45 & -2.64 & -3.11 & -3.13 & -3.01 & -2.73 & -3.03 & -3.05 & -3.61 & -3.11 & -2.75 & -3.37 & -2.90 \\
\hline Pakistan & & & & & & -3.18 & -2.42 & -2.89 & -3.27 & -3.71 & -4.44 & -4.04 & -4.34 & -4.17 & -3.62 & -4.22 & -4.02 & -4.44 & -4.31 & -3.79 \\
\hline Paraguay & & & & & & -0.43 & -2.32 & -1.92 & -1.58 & -0.82 & -0.83 & 0.29 & -0.25 & -2.10 & -0.36 & -1.21 & -2.27 & -2.38 & -2.20 & -1.31 \\
\hline Peru & & & & & & -0.43 & -1.92 & -1.99 & -0.80 & -0.25 & -0.99 & -0.77 & -3.46 & -3.37 & -2.96 & -2.49 & -2.69 & -2.77 & -1.38 & -1.88 \\
\hline Philippines & & & & -1.31 & -0.95 & -1.49 & -2.03 & -2.02 & -2.25 & -2.34 & -1.97 & -2.67 & -3.43 & -2.42 & -1.32 & -1.29 & -0.94 & -2.84 & -4.07 & -2.08 \\
\hline Poland & & & & & & -0.26 & -1.64 & -1.65 & -1.90 & -2.82 & -2.76 & -2.63 & -3.56 & -3.41 & -3.17 & -3.00 & -3.55 & -3.54 & -3.63 & -2.68 \\
\hline Portugal & & -1.44 & -1.15 & -1.32 & -1.71 & -1.75 & -1.10 & -1.49 & -1.53 & -1.87 & -1.65 & -1.80 & -1.22 & -1.92 & -1.80 & -1.19 & -1.23 & -1.18 & -1.60 & -1.47 \\
\hline Romania & & & & & & & & & & & 1.92 & 1.35 & 1.75 & -1.25 & -1.45 & -2.11 & -2.85 & -2.46 & -3.05 & -0.91 \\
\hline
\end{tabular}




\begin{tabular}{|c|c|c|c|c|c|c|c|c|c|c|c|c|c|c|c|c|c|c|c|c|}
\hline Russia & & & & & & & 1.63 & 1.23 & 2.84 & 2.55 & -2.20 & -4.14 & -1.16 & -2.35 & -2.82 & -3.59 & -4.27 & -3.05 & -3.58 & -1.45 \\
\hline Senegal & & & & & & & -4.20 & -4.80 & -3.15 & -2.72 & -2.23 & -1.72 & -2.96 & -2.25 & -2.97 & -2.90 & -2.87 & -3.69 & -2.80 & -3.02 \\
\hline Singapore & & & & & -2.60 & -3.19 & -3.48 & -3.16 & -3.00 & -2.65 & -4.30 & -3.84 & -2.97 & -2.62 & -3.47 & -2.46 & -3.30 & -1.63 & -1.58 & -2.95 \\
\hline South Africa & & & & & -1.81 & -2.18 & -1.45 & -1.37 & -2.08 & -0.91 & -2.15 & -2.27 & -1.82 & -2.36 & -2.99 & -1.58 & -1.14 & -1.91 & -0.58 & -1.77 \\
\hline Spain & & -2.42 & -2.77 & -2.72 & -2.72 & -3.25 & -3.13 & -3.83 & -3.41 & -3.76 & -3.56 & -3.00 & -3.14 & -3.70 & -3.93 & -3.27 & -3.66 & -2.40 & -4.12 & -3.16 \\
\hline Sri Lanka & & & & & & -2.63 & -2.13 & -2.08 & -1.85 & -2.09 & -2.20 & -2.67 & -3.40 & -3.26 & -3.84 & -4.05 & -4.07 & -3.26 & -3.01 & -2.90 \\
\hline Sweden & & -1.56 & -1.52 & -1.56 & -2.44 & -1.44 & -1.08 & -1.83 & -1.68 & -2.00 & -1.77 & -2.13 & -2.11 & -1.17 & -1.51 & -1.30 & -1.22 & -1.40 & -1.56 & -1.60 \\
\hline Switzerland & & -3.24 & -3.20 & -3.05 & -3.22 & -3.66 & -3.42 & -3.69 & -3.41 & -3.49 & -3.28 & -2.87 & -2.74 & -2.75 & -3.11 & -3.76 & -3.31 & -3.34 & -3.24 & -3.18 \\
\hline Tanzania & & & & & & & & & & & & & & & & & & -2.96 & -2.57 & -2.77 \\
\hline Thailand & & -3.27 & -3.61 & -3.42 & -3.58 & -4.05 & -4.04 & -3.77 & -4.14 & -4.54 & -4.43 & -5.08 & -5.79 & -5.71 & -4.03 & -4.98 & -4.54 & -4.31 & -4.83 & -4.34 \\
\hline Tunisia & & & & & & -4.04 & -3.88 & -4.13 & -4.10 & -4.15 & -4.34 & -4.14 & -4.10 & -4.33 & -4.43 & -4.86 & -4.81 & -4.91 & -5.11 & -4.38 \\
\hline Turkey & & 0.47 & -2.05 & -1.31 & -1.11 & -0.93 & 2.74 & 2.53 & 0.10 & 0.61 & -0.59 & -0.54 & -1.95 & -1.62 & -0.82 & -0.25 & -1.45 & 0.14 & 1.08 & -0.28 \\
\hline Uganda & & & & & & & -1.41 & -1.75 & -1.23 & -2.78 & -1.68 & -1.58 & -1.30 & 0.79 & 1.17 & -0.28 & 0.43 & 0.54 & 0.76 & -0.64 \\
\hline UK & & -4.53 & -4.45 & -3.93 & -3.91 & -2.82 & -3.24 & -3.45 & -4.00 & -3.45 & -3.35 & -1.37 & -3.93 & -4.08 & -4.17 & -4.55 & -3.77 & -4.64 & -4.72 & -3.66 \\
\hline Ukraine & & & & & & & 0.12 & 10.85 & 9.24 & 5.80 & 2.62 & 2.25 & -0.99 & -1.74 & -1.98 & -2.55 & -3.46 & -3.14 & -3.78 & 1.02 \\
\hline Uruguay & & & & & & -4.11 & -1.79 & -1.66 & -1.86 & -2.43 & -3.79 & -3.49 & -2.97 & -3.84 & -3.95 & -7.23 & -3.08 & -4.70 & -3.83 & -3.48 \\
\hline USA & & -7.03 & -6.38 & -6.55 & -5.28 & -5.09 & -4.90 & -4.80 & -4.85 & -4.74 & -4.75 & -4.69 & -4.98 & -4.94 & -5.02 & -4.94 & -5.02 & -4.80 & -4.69 & -5.19 \\
\hline Venezuela & & -1.15 & -0.74 & -0.67 & -0.02 & 0.03 & -1.03 & -1.05 & -2.09 & -2.00 & -1.31 & -1.39 & -0.73 & -0.95 & -0.02 & -0.96 & -0.85 & 0.19 & -1.01 & -0.88 \\
\hline Vietnam & & & & & & -2.64 & -2.25 & -1.58 & -1.96 & -2.18 & -2.75 & -2.86 & -2.75 & -3.04 & -3.27 & -2.92 & -2.98 & -3.28 & -3.34 & -2.70 \\
\hline Zimbabwe & & & & & & & -3.37 & -2.89 & -1.59 & -1.06 & -1.46 & 0.24 & 2.72 & 4.33 & 4.54 & 2.49 & 1.26 & 1.52 & 1.63 & 0.64 \\
\hline Mean & -2.79 & -3.13 & -2.78 & -2.70 & -2.87 & -2.71 & -2.47 & -2.67 & -2.64 & -2.60 & -2.82 & -2.79 & -2.94 & -3.04 & -2.89 & -3.03 & -2.96 & -2.84 & -2.75 & -2.79 \\
\hline
\end{tabular}

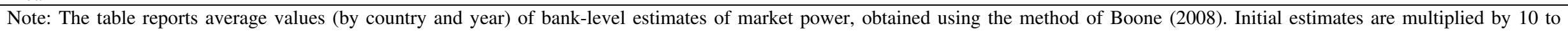
improve the expositional quality of the results. More negative values reflect higher competition. 
Table 2

Institutional and other determinants of bank market power

\begin{tabular}{|c|c|c|c|c|c|c|c|c|c|}
\hline & \multicolumn{6}{|c|}{ Panel A: Direct identification } & \multicolumn{3}{|c|}{ Panel B: Identification through bank characteristics } \\
\hline & $\begin{array}{l}(1) \\
\text { Basic } \\
\text { equation } \\
\end{array}$ & $\begin{array}{l}(2) \\
\text { All } \\
\text { controls }\end{array}$ & $\begin{array}{l}(3) \\
\text { IV } \\
\text { regression }\end{array}$ & $\begin{array}{l}(4) \\
\text { Low-income } \\
\text { countries }\end{array}$ & $\begin{array}{l}(5) \\
\text { High-income } \\
\text { countries }\end{array}$ & $\begin{array}{l}(6) \\
\text { Combined } \\
\text { effects }\end{array}$ & $\begin{array}{l}\text { (1) } \\
\text { All countries }\end{array}$ & $\begin{array}{l}(2) \\
\text { Low-income } \\
\text { countries }\end{array}$ & $\begin{array}{l}(3) \\
\text { High-income } \\
\text { countries }\end{array}$ \\
\hline Market power lagged & $\begin{array}{l}0.454 * * * \\
(16.12)\end{array}$ & $\begin{array}{l}0.412 * * * \\
(15.19)\end{array}$ & & $\begin{array}{l}0.712 * * * \\
(24.44)\end{array}$ & $\begin{array}{l}0.293 * * * \\
(13.01)\end{array}$ & $\begin{array}{l}0.387 * * * \\
(14.87)\end{array}$ & $\begin{array}{l}0.380 * * * \\
(12.50)\end{array}$ & $\begin{array}{l}0.655 * * * \\
(17.64)\end{array}$ & $\begin{array}{l}0.309 * * * \\
(9.43)\end{array}$ \\
\hline Financial reform & $\begin{array}{l}-0.039 * * * \\
(-4.53)\end{array}$ & $\begin{array}{l}-0.031 * * * \\
(-3.08)\end{array}$ & $\begin{array}{l}-0.040 * * * \\
(-4.53)\end{array}$ & $\begin{array}{l}0.044 * * * \\
(2.84)\end{array}$ & $\begin{array}{l}-0.062 * * * \\
(-3.32)\end{array}$ & $\begin{array}{l}-0.023^{* *} \\
(-2.36)\end{array}$ & $\begin{array}{l}-0.027 * * \\
(-2.45)\end{array}$ & $\begin{array}{l}-0.020 * \\
(-1.90)\end{array}$ & $\begin{array}{l}-0.037 * * \\
(-2.50)\end{array}$ \\
\hline Transparency & $\begin{array}{l}-0.104 * * * \\
(-3.12)\end{array}$ & $\begin{array}{l}-0.117 * * * \\
(-3.19)\end{array}$ & $\begin{array}{l}-0.130 * * * \\
(-3.48)\end{array}$ & $\begin{array}{l}-0.092 * * * \\
(-2.82)\end{array}$ & $\begin{array}{l}-0.095 * * * \\
(-2.83)\end{array}$ & $\begin{array}{l}-0.103 * * * \\
(-2.84)\end{array}$ & $\begin{array}{l}-0.116^{* * *} \\
(-3.01)\end{array}$ & $\begin{array}{l}-0.095 * * * \\
(-3.02)\end{array}$ & $\begin{array}{l}-0.071 * * * \\
(-2.70)\end{array}$ \\
\hline Law quality & $\begin{array}{l}-0.101 * * * \\
(-3.44)\end{array}$ & $\begin{array}{l}-0.081 * * \\
(-2.53)\end{array}$ & $\begin{array}{l}-0.075^{* *} \\
(-2.28)\end{array}$ & $\begin{array}{l}-0.115 * * * \\
(-3.27)\end{array}$ & $\begin{array}{l}-0.050 \\
(-0.92)\end{array}$ & $\begin{array}{l}-0.115 * * * \\
(-3.62)\end{array}$ & $\begin{array}{l}-0.101 * * * \\
(-2.76)\end{array}$ & $\begin{array}{l}-0.066^{* *} \\
(-2.01)\end{array}$ & $\begin{array}{l}-0.047 \\
(-0.86)\end{array}$ \\
\hline Bureaucratic quality & $\begin{array}{l}-0.423 * * * \\
(-9.52)\end{array}$ & $\begin{array}{l}-0.391 * * * \\
(-5.24)\end{array}$ & $\begin{array}{l}-0.385 * * * \\
(-4.90)\end{array}$ & $\begin{array}{l}-0.294 * * * \\
(-2.98)\end{array}$ & $\begin{array}{l}-0.247 * * \\
(-2.49)\end{array}$ & $\begin{array}{l}-0.389 * * * \\
(-5.48)\end{array}$ & $\begin{array}{l}-0.350 * * * \\
(-4.82)\end{array}$ & $\begin{array}{l}-0.307 * * * \\
(-3.21)\end{array}$ & $\begin{array}{l}-0.280 * * * \\
(-2.83)\end{array}$ \\
\hline Capitalization & $\begin{array}{l}0.125 * * * \\
(7.14)\end{array}$ & $\begin{array}{l}0.112 * * * \\
(6.52)\end{array}$ & $\begin{array}{l}0.114 * * * \\
(6.60)\end{array}$ & $\begin{array}{l}0.302 * * * \\
(12.31)\end{array}$ & $\begin{array}{l}0.093 * * * \\
(5.02)\end{array}$ & $\begin{array}{l}0.115 * * * \\
(6.57)\end{array}$ & $\begin{array}{l}0.085 * * * \\
(4.41)\end{array}$ & $\begin{array}{l}0.162 * * * \\
(7.10)\end{array}$ & $\begin{array}{l}0.061 * * * \\
(2.75)\end{array}$ \\
\hline Bank size & $\begin{array}{l}0.036 * * * \\
(9.23)\end{array}$ & $\begin{array}{l}0.038 * * * \\
(9.50)\end{array}$ & $\begin{array}{l}0.030 * * * \\
(7.14)\end{array}$ & $\begin{array}{l}0.061 * * * \\
(16.27)\end{array}$ & $\begin{array}{l}0.025^{* * *} \\
(4.03)\end{array}$ & $\begin{array}{l}0.040 * * * \\
(9.63)\end{array}$ & $\begin{array}{l}0.022 * * * \\
(3.50)\end{array}$ & $\begin{array}{l}0.030 * * * \\
(5.22)\end{array}$ & $\begin{array}{l}0.011 * * \\
(1.99)\end{array}$ \\
\hline Concentration & & $\begin{array}{l}0.253^{*} \\
(1.71)\end{array}$ & $\begin{array}{l}0.201 \\
(1.48)\end{array}$ & $\begin{array}{l}0.403 * * * \\
(3.03)\end{array}$ & $\begin{array}{l}-0.012 \\
(-0.09)\end{array}$ & $\begin{array}{l}0.261^{*} \\
(1.80)\end{array}$ & $\begin{array}{l}0.193 \\
(1.50)\end{array}$ & $\begin{array}{l}0.282 * * \\
(2.41)\end{array}$ & $\begin{array}{l}0.016 \\
(0.05)\end{array}$ \\
\hline GDP per capita & & $\begin{array}{l}-0.579 * * * \\
(-4.35)\end{array}$ & $\begin{array}{l}-0.308 * * * \\
(-2.82)\end{array}$ & $\begin{array}{l}-0.547 * * * \\
(-4.25)\end{array}$ & $\begin{array}{l}-0.118 \\
(-1.07)\end{array}$ & $\begin{array}{l}-0.566 * * * \\
(-4.29)\end{array}$ & $\begin{array}{l}-0.504 * * * \\
(-4.02)\end{array}$ & $\begin{array}{l}-0.516^{* * *} \\
(-6.20)\end{array}$ & $\begin{array}{l}-0.094 \\
(-0.90)\end{array}$ \\
\hline GDP growth & & $\begin{array}{l}0.004 \\
(0.79)\end{array}$ & $\begin{array}{l}0.005 \\
(0.92)\end{array}$ & $\begin{array}{l}0.018 * * \\
(2.20)\end{array}$ & $\begin{array}{l}0.009 \\
(0.80)\end{array}$ & $\begin{array}{l}0.004 \\
(0.79)\end{array}$ & $\begin{array}{l}0.002 \\
(0.26)\end{array}$ & $\begin{array}{l}0.006 \\
(0.39)\end{array}$ & $\begin{array}{l}0.015^{*} \\
(1.70)\end{array}$ \\
\hline Inflation & & $\begin{array}{l}0.019 * * * \\
(3.12)\end{array}$ & $\begin{array}{l}0.015^{* * * *} \\
(2.90)\end{array}$ & $\begin{array}{l}0.025 * * * \\
(3.66)\end{array}$ & $\begin{array}{l}0.010 * * \\
(2.37)\end{array}$ & $\begin{array}{l}0.019 * * * \\
(3.11)\end{array}$ & $\begin{array}{l}0.020 * * * \\
(2.90)\end{array}$ & $\begin{array}{l}0.023 * * * \\
(3.14)\end{array}$ & $\begin{array}{l}0.015 * * * \\
(2.77)\end{array}$ \\
\hline $\begin{array}{l}\text { Financial reform * } \\
\text { transparency }\end{array}$ & & & & & & $\begin{array}{l}-0.011 * * * \\
(-2.99)\end{array}$ & & & \\
\hline $\begin{array}{l}\text { Financial reform * } \\
\text { law quality }\end{array}$ & & & & & & $\begin{array}{l}-0.021 * * * \\
(-2.94)\end{array}$ & & & \\
\hline $\begin{array}{l}\text { Financial reform * } \\
\text { bureaucratic quality }\end{array}$ & & & & & & $\begin{array}{l}-0.014 * \\
(-1.94)\end{array}$ & & & \\
\hline $\begin{array}{l}\text { Financial reform * } \\
\text { GDP per capita }\end{array}$ & & & & & & $\begin{array}{l}-0.016 * * * \\
(-2.90)\end{array}$ & & & \\
\hline
\end{tabular}




\begin{tabular}{|c|c|c|c|c|c|c|c|c|c|}
\hline $\begin{array}{l}\text { Financial reform * } \\
\text { bank size }\end{array}$ & & & & & & & $\begin{array}{l}-0.000 * * \\
(-2.14)\end{array}$ & $\begin{array}{l}-0.000 * \\
(-1.70)\end{array}$ & $\begin{array}{l}-0.001 * * * \\
(-3.07)\end{array}$ \\
\hline $\begin{array}{l}\text { Transparency * bank } \\
\text { size }\end{array}$ & & & & & & & $\begin{array}{l}-0.008 * * * \\
(-4.05)\end{array}$ & $\begin{array}{l}-0.007 * * * \\
(-5.19)\end{array}$ & $\begin{array}{l}-0.006 * * * \\
(-4.76)\end{array}$ \\
\hline $\begin{array}{l}\text { Law quality } * \text { bank } \\
\text { size }\end{array}$ & & & & & & & $\begin{array}{l}-0.007 * * * \\
(-3.29)\end{array}$ & $\begin{array}{l}-0.004 * * \\
(-2.50)\end{array}$ & $\begin{array}{l}-0.006^{* * * *} \\
(-3.16)\end{array}$ \\
\hline $\begin{array}{l}\text { Bureaucratic quality } \\
* \text { bank size }\end{array}$ & & & & & & & $\begin{array}{l}-0.012 * * * \\
(-7.18)\end{array}$ & $\begin{array}{l}-0.012 * * * \\
(-10.22)\end{array}$ & $\begin{array}{l}-0.006^{* *} \\
(-2.38)\end{array}$ \\
\hline $\begin{array}{l}\text { Financial reform * } \\
\text { capitalization }\end{array}$ & & & & & & & $\begin{array}{l}-0.000 * * \\
(-2.40)\end{array}$ & $\begin{array}{l}-0.000 \\
(-0.90)\end{array}$ & $\begin{array}{l}-0.000 * * \\
(-2.55)\end{array}$ \\
\hline $\begin{array}{l}\text { Transparency * } \\
\text { capitalization }\end{array}$ & & & & & & & $\begin{array}{l}-0.002 * * \\
(-2.21)\end{array}$ & $\begin{array}{l}-0.000 \\
(-0.65)\end{array}$ & $\begin{array}{l}-0.003 * * \\
(-2.30)\end{array}$ \\
\hline $\begin{array}{l}\text { Law quality * } \\
\text { capitalization }\end{array}$ & & & & & & & $\begin{array}{l}-0.000 \\
(-0.74)\end{array}$ & $\begin{array}{l}-0.000 \\
(-0.10)\end{array}$ & $\begin{array}{l}0.015 \\
(0.21)\end{array}$ \\
\hline $\begin{array}{l}\text { Bureaucratic quality } \\
* \text { capitalization } \\
\end{array}$ & & & & & & & $\begin{array}{l}0.000 \\
(0.18) \\
\end{array}$ & $\begin{array}{l}0.001 \\
(0.50) \\
\end{array}$ & $\begin{array}{l}-0.000 \\
(-0.12) \\
\end{array}$ \\
\hline Bank observations & 82,161 & 81,713 & 81,713 & 32,454 & 27,877 & 81,713 & 81,713 & 81,713 & 81,713 \\
\hline Country observations & 1,181 & 1,181 & 1,181 & 469 & 403 & 1,181 & 1,181 & 1,181 & 1,181 \\
\hline Sargan (p-value) & 0.307 & 0.382 & 0.295 & 0.141 & 0.250 & 0.300 & 0.407 & 0.282 & 0.166 \\
\hline AR1 (p-value) & 0.114 & 0.080 & 0.093 & 0.112 & 0.080 & 0.115 & 0.103 & 0.064 & 0.079 \\
\hline AR2 (p-value) & 0.026 & 0.008 & 0.031 & 0.027 & 0.020 & 0.012 & 0.022 & 0.006 & 0.040 \\
\hline
\end{tabular}

Note: The table presents coefficients and t-statistics (in parentheses) of determinants of market power, as measured by the Boone indicator. Estimation method is system GMM for dynamic panels, except from regression (3) of Panel A, which is carried out using an instrumental variables method for panel data. All equations include countryspecific time-effects. Sargan is the p-value of the Sargan test for overidentifying restrictions. AR1 and AR2 are the p-values of the tests for first and second order autocorrelation, respectively. $* * *$ and $* * *$ denote statistical significance at the 10,5 and $1 \%$ level, respectively. 
Table 3

Sensitivity analysis using the Lerner index and the 3-bank concentration ratio as dependent variables

\begin{tabular}{|c|c|c|c|c|}
\hline & $\begin{array}{l}\text { (1) } \\
\text { Lerner index } \\
\text { equation }\end{array}$ & $\begin{array}{l}(2) \\
\text { Lerner index } \\
\text { equation }\end{array}$ & $\begin{array}{l}(3) \\
\text { Concentration } \\
\text { equation }\end{array}$ & $\begin{array}{l}\text { (4) } \\
\text { Concentration } \\
\text { equation }\end{array}$ \\
\hline Market power lagged & $\begin{array}{l}0.406 * * * \\
(7.12)\end{array}$ & $\begin{array}{l}0.381 * * * \\
(6.68)\end{array}$ & $\begin{array}{l}0.911 * * * \\
(99.47)\end{array}$ & $\begin{array}{l}0.873 * * * \\
(66.22)\end{array}$ \\
\hline Financial reform & $\begin{array}{l}-0.022^{* *} \\
(-2.14)\end{array}$ & $\begin{array}{l}-0.019 * \\
(-1.83)\end{array}$ & $\begin{array}{l}0.003 * * * \\
(6.39)\end{array}$ & $\begin{array}{l}0.003 * * * \\
(5.81)\end{array}$ \\
\hline Transparency & $\begin{array}{l}-0.404 * * * \\
(-5.03)\end{array}$ & $\begin{array}{l}-0.307 * * * \\
(-3.41)\end{array}$ & $\begin{array}{l}0.002 \\
(1.56)\end{array}$ & $\begin{array}{l}0.001 \\
(0.64)\end{array}$ \\
\hline Law quality & $\begin{array}{l}-0.250 * * \\
(-1.98)\end{array}$ & $\begin{array}{l}-0.125 \\
(-0.90)\end{array}$ & $\begin{array}{l}-0.003^{*} \\
(-1.69)\end{array}$ & $\begin{array}{l}-0.003^{*} \\
(-1.72)\end{array}$ \\
\hline Bureaucratic quality & $\begin{array}{l}-0.407 * * * \\
(-3.20)\end{array}$ & $\begin{array}{l}-0.362 * * * \\
(-2.99)\end{array}$ & $\begin{array}{l}-0.003 \\
(-1.29)\end{array}$ & $\begin{array}{l}-0.003 \\
(-1.22)\end{array}$ \\
\hline Capitalization & $\begin{array}{l}0.095 * * * \\
(7.10)\end{array}$ & $\begin{array}{l}0.081 * * * \\
(5.24)\end{array}$ & $\begin{array}{l}0.008 * * \\
(2.19)\end{array}$ & $\begin{array}{l}0.007 * * \\
(2.03)\end{array}$ \\
\hline Bank size & $\begin{array}{l}0.193 * * * \\
(3.03)\end{array}$ & $\begin{array}{l}0.176 * * * \\
(2.95)\end{array}$ & $\begin{array}{l}0.015 * * * \\
(3.15)\end{array}$ & $\begin{array}{l}0.017 * * * \\
(3.44)\end{array}$ \\
\hline Concentration & $\begin{array}{l}0.011 \\
(0.91)\end{array}$ & $\begin{array}{l}0.025 \\
(1.32)\end{array}$ & & \\
\hline GDP per capita & $\begin{array}{l}-0.310 * * \\
(-2.35)\end{array}$ & $\begin{array}{l}-0.317 * * \\
(-2.41)\end{array}$ & $\begin{array}{l}0.004 \\
(1.62)\end{array}$ & $\begin{array}{l}0.003 \\
(1.05)\end{array}$ \\
\hline GDP growth & $\begin{array}{l}0.017 \\
(0.62)\end{array}$ & $\begin{array}{l}0.002 \\
(0.12)\end{array}$ & $\begin{array}{l}-0.001 * * * \\
(-2.66)\end{array}$ & $\begin{array}{l}-0.002 * * * \\
(-2.84)\end{array}$ \\
\hline Inflation & $\begin{array}{l}0.030 * * * \\
(3.86)\end{array}$ & $\begin{array}{l}0.025 * * * \\
(3.44)\end{array}$ & $\begin{array}{l}0.003 * * * \\
(4.65)\end{array}$ & $\begin{array}{l}0.003 * * * \\
(4.52)\end{array}$ \\
\hline $\begin{array}{l}\text { Financial reform * } \\
\text { bank size }\end{array}$ & & $\begin{array}{l}-0.000 * \\
(-1.88)\end{array}$ & & $\begin{array}{l}-0.001 * * \\
(-2.20)\end{array}$ \\
\hline $\begin{array}{l}\text { Transparency * bank } \\
\text { size }\end{array}$ & & $\begin{array}{l}-0.004 * * \\
(-2.17)\end{array}$ & & $\begin{array}{l}-0.002 \\
(-1.03)\end{array}$ \\
\hline $\begin{array}{l}\text { Law quality } * \text { bank } \\
\text { size }\end{array}$ & & $\begin{array}{l}-0.000 \\
(-1.11)\end{array}$ & & $\begin{array}{l}-0.000 \\
(-0.02)\end{array}$ \\
\hline $\begin{array}{l}\text { Bureaucratic quality * } \\
\text { bank size }\end{array}$ & & $\begin{array}{l}-0.008 * * \\
(-2.43)\end{array}$ & & $\begin{array}{l}0.002 \\
(0.25)\end{array}$ \\
\hline $\begin{array}{l}\text { Financial reform * } \\
\text { capitalization }\end{array}$ & & $\begin{array}{l}-0.000 * * \\
(-2.29)\end{array}$ & & $\begin{array}{l}-0.001 * * \\
(-2.38)\end{array}$ \\
\hline $\begin{array}{l}\text { Transparency * } \\
\text { capitalization }\end{array}$ & & $\begin{array}{l}-0.008^{* * *} \\
(-3.17)\end{array}$ & & $\begin{array}{l}-0.003 \\
(-0.72)\end{array}$ \\
\hline $\begin{array}{l}\text { Law quality } * \\
\text { capitalization }\end{array}$ & & $\begin{array}{l}0.001 \\
(0.28)\end{array}$ & & $\begin{array}{l}0.000 \\
(0.16)\end{array}$ \\
\hline $\begin{array}{l}\text { Bureaucratic quality * } \\
\text { capitalization }\end{array}$ & & $\begin{array}{l}-0.003 * \\
(-1.78) \\
\end{array}$ & & $\begin{array}{l}-0.001 \\
(-0.41)\end{array}$ \\
\hline Bank obs. & 81,713 & 81,713 & 81,713 & 81,713 \\
\hline Country obs. & 1,181 & 1,181 & 1,181 & 1,181 \\
\hline Sargan (p-value) & 0.096 & 0.212 & 0.109 & 0.112 \\
\hline $\operatorname{AR}(1)$ (p-value) & 0.042 & 0.014 & 0.105 & 0.124 \\
\hline $\mathrm{AR}(2)$ (p-value) & 0.007 & 0.003 & 0.038 & 0.046 \\
\hline
\end{tabular}

Note: The table presents coefficients and t-statistics (in parentheses) of determinants of market power. Dependent variable in columns (1)-(2) is the Lerner index, and in columns (3)-(4) the 3-bank concentration ratio. Columns (1)-(2) include country-specific time-effects and the rest simple time effects. Sargan is the p-value of the Sargan test for overidentifying restrictions. AR1 and AR2 are the pvalues of the tests for first and second order autocorrelation, respectively. $*$, ** and *** denote statistical significance at the 10,5 and $1 \%$ level, respectively. 


\section{Figure 1}

Changes in competition between groups of countries

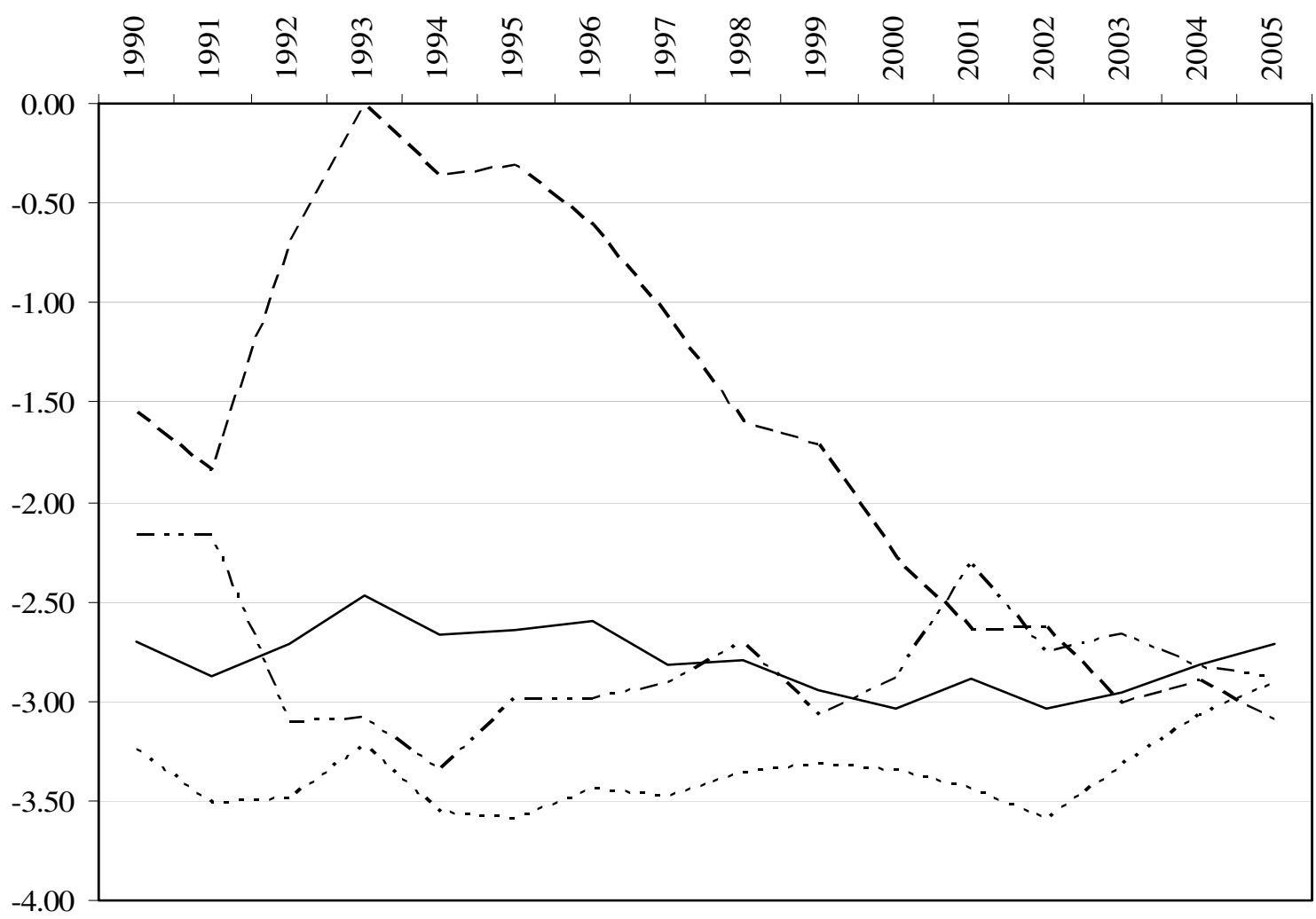

All countries

- . . . High-income countries

- - - Transition countries

- . - - Lower middle and low-income coutnries 